\title{
Assessment of river water-groundwater-seawater interactions in the coastal delta of Bangladesh based on hydrochemistry and salinity distribution
}

\author{
Sushanta Kumar Roy ${ }^{1} \cdot$ Anwar Zahid ${ }^{2,3}$
}

Received: 3 September 2020 / Accepted: 16 February 2021 / Published online: 4 March 2021

(c) The Author(s) 2021 OPEN

\begin{abstract}
A synchronization study among hydrochemistry, hydrochemical facies evaluation, EC observation, salinity distribution and groundwater flow direction has been addressed to assess river water-groundwater-seawater interactions in the coastal delta of southern Bangladesh. The findings show that river water, shallow groundwater and deep groundwater interact with seawater at various intensities within the complex dynamics of hydrochemical facies evaluation. Deep groundwater is intensively influenced by seawater, where shallow groundwater is moderately affected and river water is very negligibly affected. Major cation and anion have been plotted in the Piper diagrams and hydrochemical facies diagrams (HFE-D) to clarify the result. More than $60 \%$ of the water samples of the river lie on the $\mathrm{Ca}-\mathrm{HCO}_{3}\left(\mathrm{or} \mathrm{Mg}-\mathrm{HCO}{ }_{3}\right.$ ) facies quadrant, and more than $70 \%$ of the shallow groundwater samples and more than $95 \%$ of the deep groundwater samples lie on the $\mathrm{Na}-\mathrm{Cl}$ facies quadrant of the HFE-D diagram. River water types are dissimilar, and approximately $82 \%$ of facies are characterized by freshening phases and $18 \%$ by intrusion phases. Mixed water types with predominate of $\mathrm{Na}-\mathrm{Cl}$ were observed in shallow groundwater where the hydrochemical facies are characterized by 53 percent freshening phases and 47 percent intrusion phases. Deep groundwater hydrochemistry clearly indicates the dominant $\mathrm{Na}-\mathrm{Cl}$ type of water in the study area where only four hydrochemical facies are observed and 78 percent correspond to the intrusion phases and 22 percent to the freshening phases. Both direct and reverse cation exchange reactions take place in shallow groundwater, where deep groundwater is predominantly characterized by reverse cation exchange reactions. Two end members: seawater of Bay of Bengal and freshwater, contribute to the exchange reactions in the coastal aquifer of the study area. In terms of nitrate contamination, river waters are affected by negligible to low concentrations, shallow groundwater is affected by moderate to high concentrations and deep groundwater is affected by moderate to very high nitrate concentrations. Dissimilarity in electrical conductivity $(\mathrm{EC})$ values, variation of salinity distribution maps and groundwater flow direction suggest the possible interconnections among river water, groundwater and aquifer sediments. Significant concentrations of $\mathrm{Na}^{+}$and $\mathrm{Cl}^{-}$ions lead to seawater contamination in groundwater, and $\mathrm{HCO}_{3}{ }^{-}$along with $\mathrm{Na}^{+}, \mathrm{Ca}^{2+}, \mathrm{Mg}^{2+}$ in river water suggests mixing of freshwater and seawater, which could have adverse effects both in coastal delta aquatic life and in agriculture.
\end{abstract}

Keywords River water · Groundwater · Seawater · Hydrochemistry · Salinity distribution · Coastal area · Bangladesh

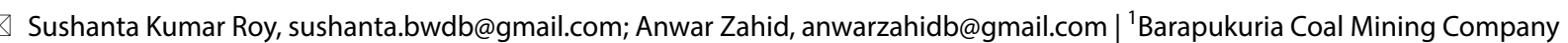
Ltd, Chowhati, Parbatipur, Dinajpur, Bangladesh. ${ }^{2}$ Ground Water Hydrology, Bangladesh Water Development Board, Dhaka,

Bangladesh. ${ }^{3}$ Department of Disaster Science and Management, University of Dhaka, Dhaka, Bangladesh. 


\section{Introduction}

River water, groundwater and seawater interaction studies are often complex and difficult tasks to perform, particularly in complex coastal hydrogeological settings. The complexities are mainly due to discrepancies in catchment physiographic characteristics, such as variations in topography, geology, climate, river geomorphology, as well as the positioning of river water features relative to groundwater flow paths in catchments, and the availability of sampling sites.

Geologically, the coastal delta of Bangladesh is more complex and dynamic than is commonly accepted. Coastal erosion, subsidence, strong tidal activity and rising sea levels are causing rapid geomorphological changes here [1]. This dynamic geology causes the coastal region to have unpredictable hydrogeological framework. The regressions and transgressions of the sea and the nature of the river over the last thousands of years have produced a complex system of sedimentary deposits comprising fresh and saline water [1, 2]. Interactions among river water, groundwater and seawater in the coastal aquifers are influenced by a variety of factors, such as sea level rise, coastal geology and hydrogeology, cyclone and storm surge activity, tidal interaction, river navigability reduction, gradient between freshwater-seawater and groundwater well pumping rates. Rising sea levels may be one of the prime reasons for intrusion of seawater into the coastal aquatic system. Research indicates that the sea level in the twenty-first century could rise by one meter or more, which would raise the vulnerable population to about one billion by $2050[3,4]$.

A huge number of hydrological and hydrogeological studies have been carried out in the Bangladesh coastal area. Some of the seawater intrusion studies are: Islam et al. [5] reported salinization and increasing amounts of metals are becoming a major threat in the coastal aquifer of the country, Naus et al. [6] referred to palaeo- and current hydrological processes and their geographical or geological controls are responsible for the variation in groundwater salinity in the southwestern coast of Bangladesh, Zahid et al. [7] depicted salinity sources in the multilayer aquifers of the coastal belt of Bengal delta, Sanchez et al. [2] delineated the saltwater intrusion into coastal groundwater systems in the southwestern coast of Bangladesh, and Rahman and Bhattacharya [8] focused exclusively on the causes of salinity intrusion into Bangladesh's coastal aquifers and $[3,4]$ studied on climate change, groundwater salinization and river salinity in the Bangladesh coastal region and stated that climate change would cause substantial changes in river salinity in the coastal area of Bangladesh by 2050 . A number of studies have also been conducted on the health issue due to salinity and other pollution in the coastal area of Bangladesh. For example, [5, 9-11] published studies on the scarcity of safe drinking water highlighting community health security impacted by saline water and other multi-hazards in coastal Bangladesh.

This study particularly focuses on the assessment of river water-groundwater-seawater interactions on the basis of hydrochemistry of water, hydrochemical facies analysis, EC observations, groundwater flow direction and salinity distribution in the coastal delta of Bangladesh. This study will provide an in-depth perception of the geological, hydrogeological and hydrochemical environments and will assess how these environments are interlinked by hydrochemistry and hydrogeology.

\section{Study area}

Ganges-Brahmaputra-Meghna (GBM) river catchment areas are one such catchment area that supplies a massive amount of runoff compared to adjacent lowland areas of the Bangladesh Coastal Delta. Major and minor rivers in the study area are considered to be significant sources of groundwater recharge; and these rivers are major components of the hydrogeological system. The coastal delta of Bangladesh is typically low-lying flood-plain land without any prominent undulating areas. Surface elevation ranges from $1.32 \mathrm{~m}$ at the southern region to $2.16 \mathrm{~m}$ at the northern region and elevation changes during both the monsoon and dry seasons, although positive elevation increases during the monsoon season due to vertical accretion of sediment [12].

Eleven upazilas (sub-district) of six districts in the southcentral coastal area of Bangladesh have been considered for this study. The study area comprises the Ganges delta plain and tidal delta plain. Geographically, the study area lies between $22.00^{\circ}$ and $23.50^{\circ}$ north latitudes and between $90.15^{\circ}$ and $90.80^{\circ}$ east longitudes (Fig. 1). Two types of groundwater sampling piezometric well stations are located in the eleven distinct lines at the 11 sites of the six (6) districts. The districts are Barguna, Patuakhali, Barishal, Lakshmipur, Chandpur and Shariatpur extending from south coastal area to the central portion of Bangladesh. Each site consists of $30 \mathrm{~m}$ depth 5 shallow wells and $100 \mathrm{~m}$ depth 5 deep wells along the single line. Total groundwater sampling stations are 110 , where 55 for shallow and 55 for deep groundwater. River water sampling stations positioned at seventeen points within twelve rivers. These north-south trending rivers are Meghna, Tentulia, Payra, Biskhali, Sandha, Sikarpur, Dhansiri, Andharmanik, Gab khan, Arial Kha, Karkhana and Naya vangani. 


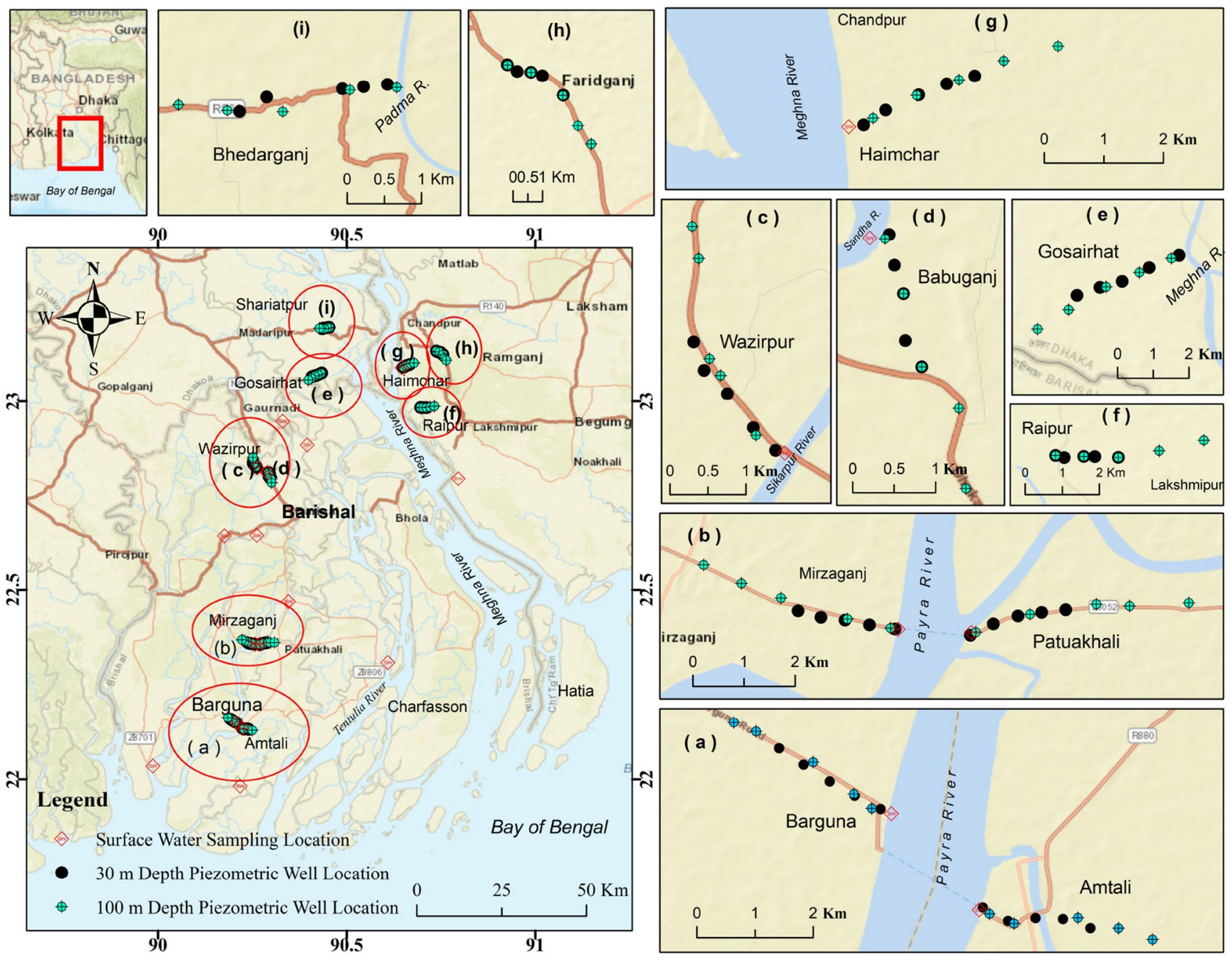

Fig. 1 Illustrating the location of groundwater sampling wells of 11 sites and 17 river water sampling stations in the coastal area of Bangladesh

\section{Materials and methods}

All data used in this study were obtained from Bangladesh Climate Change Trust (BCCT) project of Bangladesh Water Development Board (BWDB) under Ministry of Water Resources (MoWR). River water samples were collected in the months of February-March 2012 and groundwater samples collected in the months of October-November 2013. The parameters such as salinity, EC, $\mathrm{Na}, \mathrm{K}, \mathrm{Ca}, \mathrm{Mg}$, $\mathrm{Cl}, \mathrm{HCO}_{3}, \mathrm{SO}_{4}$ and $\mathrm{NO}_{3}$ have been measured in this study. Salinity and EC had been measured in the field during sampling using EC-meter and rest parameters were measured in the BWDB laboratory using the Atomic Absorption Spectrophotometer (AAS), UV-Vis Spectrophotometer and Volumetric Titration.

Groundwater flow directions have been observed through the contour map of the dry season groundwater table using contour segment of spatial analyst tools of the Arc-GIS 10.3. Interconnections between the river and the aquifers have also been assessed through graphs of electrical conductivity values.

Hydrochemical parameters have been used to determine the characterization of river water and groundwater hydrochemistry in order to assess the interaction between river water, groundwater and seawater. lons exchange and chemical reactions among various sources of water have been identified from hydrochemistry represented by the plotting of major cations and anions in the Piper diagrams. These diagrams, plotted using Aquachem 2014.2 software, are used to determine the predominant water types of the study region. Hydrochemical Facies Evaluation Diagrams (HFE-D) have been constructed in configured excel sheets to assess freshening-intrusion phases and ion exchange processes [13]. Geostatistical analyst tools Arc-Gis 10.3 have also been 
used to illustrate the salinity distribution raster maps of river water, shallow groundwater and deep groundwater.

\section{Results and discussion}

\subsection{Hydrogeological depiction}

Eleven lithological cross sections have been constructed along the $100 \mathrm{~m}$ depth line wells at eleven sites based on washed borehole sediment data (Fig. 2). Detail lithological information suggests the study area is possessed with multilayer prolific heterogeneous aquifer system composed of deltaic sediments composed of complex mixture of sand, silt, and clay. These cross sections allow us to better understand the lithology of individual sites in order to evaluate river water-groundwater interactions. Cross sections along the line wells suggest the varying nature of the aquifers at different locations, consisting of distinct stratigraphy; some aquifers are confined in nature, some unconfined, some semi-confined or leaky. The lithological dissimilarity of eleven locations in the study area may indicate variations in the hydrochemical properties of the aquifer and the nature of the interconnection between rivers and aquifers.

\subsection{Groundwater flow direction}

Based on the contour map of the groundwater table, it is found that the groundwater flow is directed from the lower to the higher values of the groundwater table in the study area. Groundwater flows from the south to the north of the delta region, where all rivers follow the topography of the study area with a general trend from the north to the Bay of Bengal in the south (Fig. 3); and when rivers are influenced by frequent tidal action, regular seasonal inflows and storm surges, the flow path moves in the opposite direction. These phenomena related to the flow direction have implications for groundwater and river water interactions. Groundwater
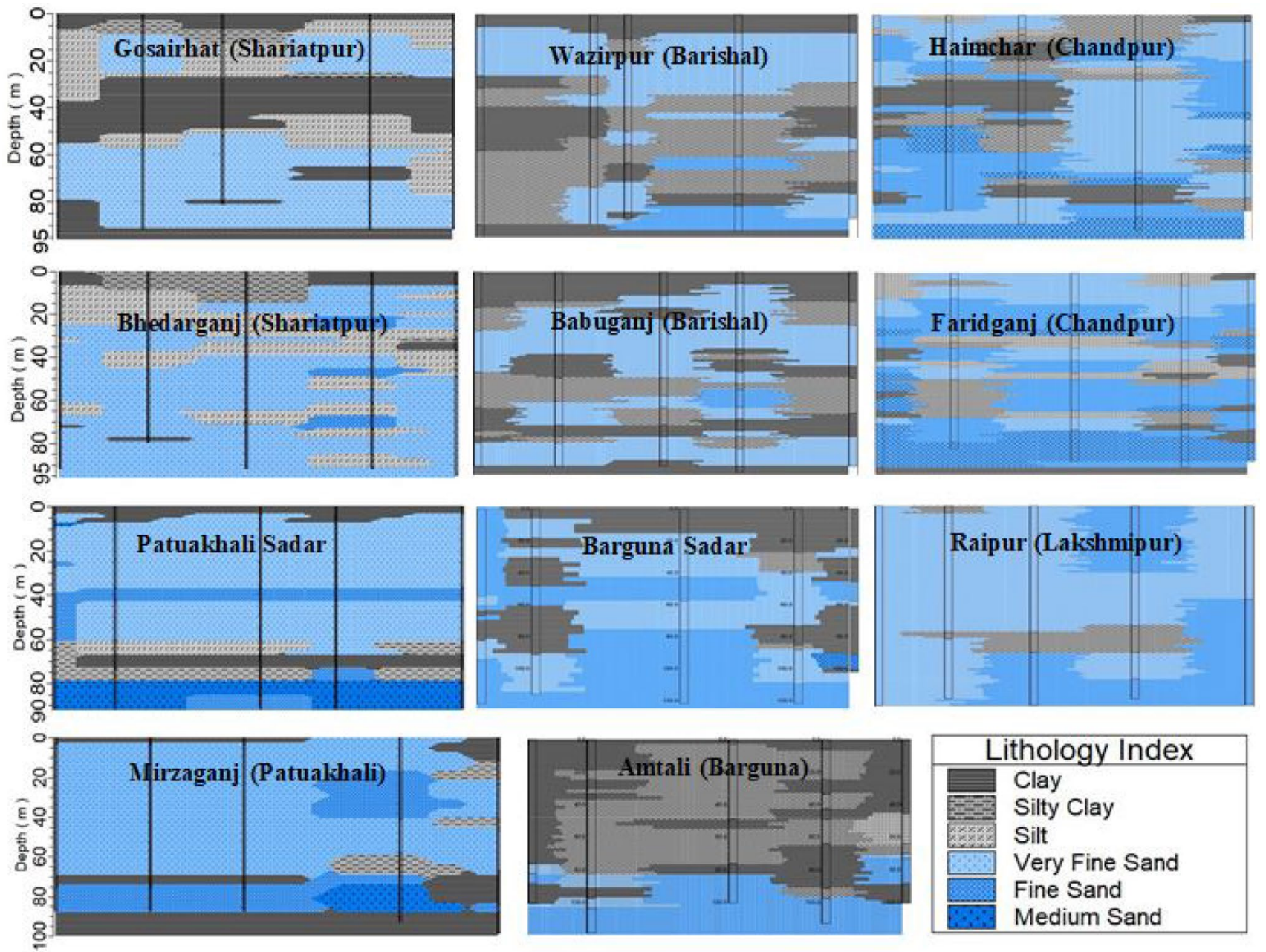

Fig. 2 Lithological cross sections along the line of approximate $100 \mathrm{~m}$ depth piezometric wells at eleven (11) locations in the study area 
Fig.3 Groundwater table contour map showing the direction of the groundwater flow

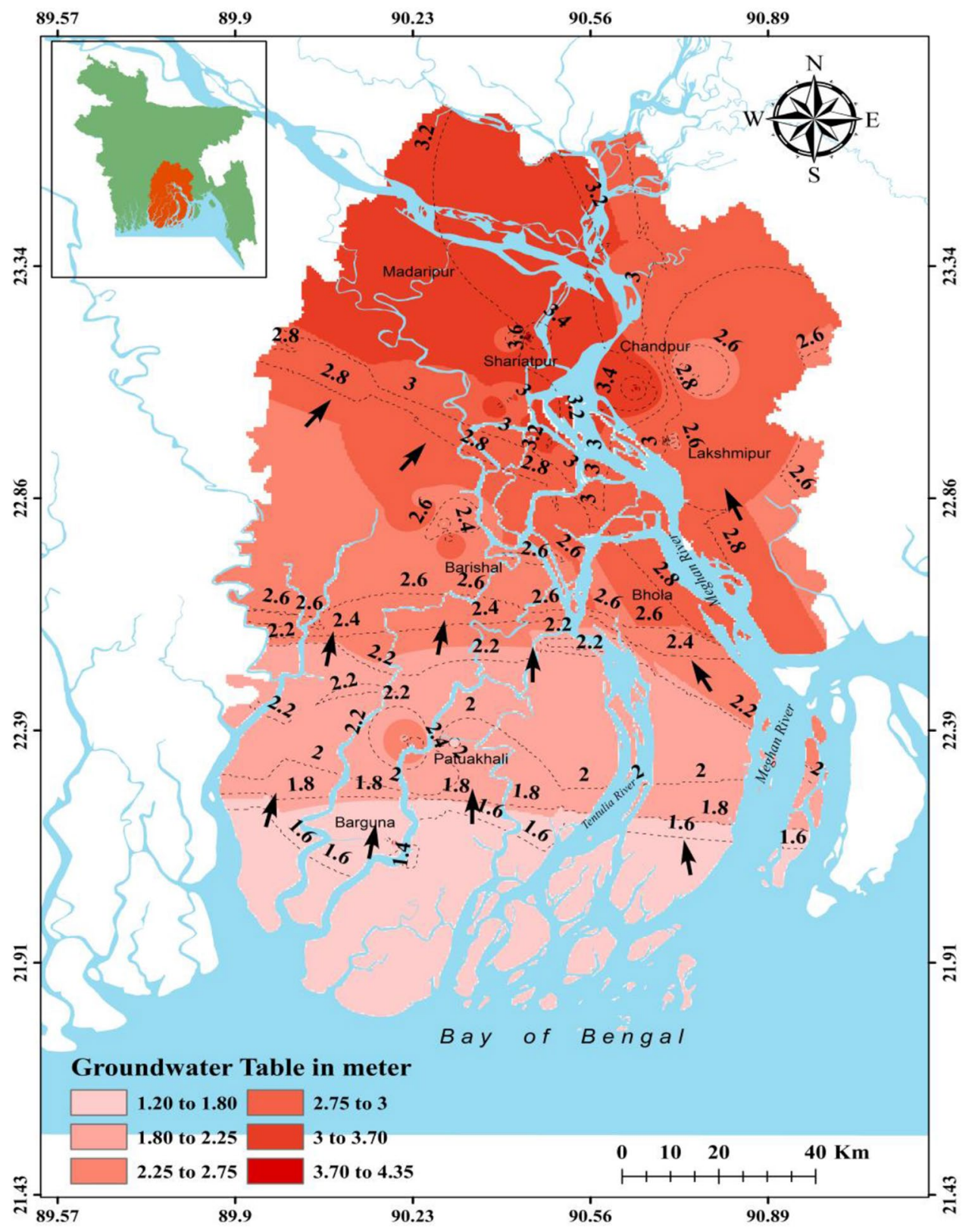

flow direction in the contour map (Fig. 3) strongly indicates the possible entrance of seawater from the Bay of Bengal to the coastal delta aquifer. River water is directly connected to groundwater in most locations due to sandy-silt lithology; and rivers and of its floodplains are significant source of groundwater recharge. When aquifers are recharged through the process of infiltration and seepage, chemical reactions, such as ion exchange, may have occurred with an approach to the interaction between river water and groundwater.

\subsection{Hydrochemical characterization of river water and groundwater}

Tables 1, 2 and 3 represent the ten hydrochemical parameters of river water samples, shallow groundwater samples and deep groundwater samples, respectively. Samples were collected during dry season of different year and period. River water sampling was performed at various times on the same day. That's why the same river exhibits different salinity levels in different sampling times. Low 


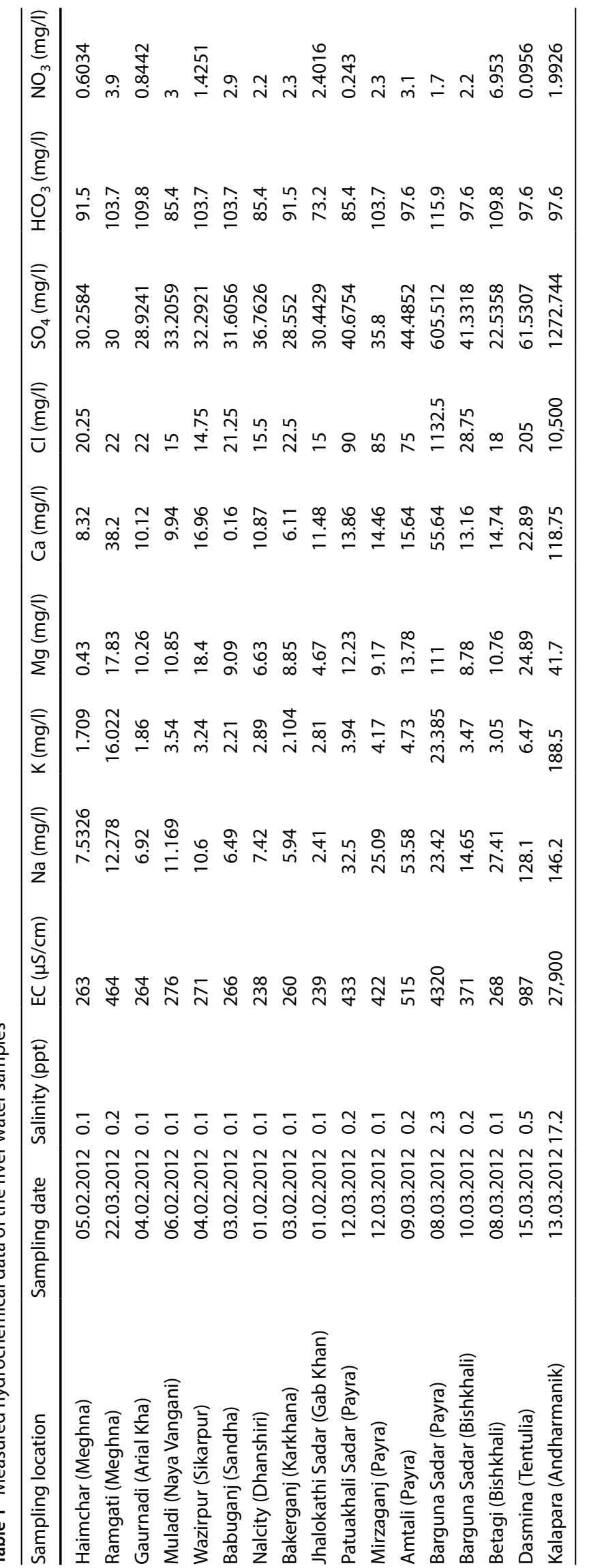




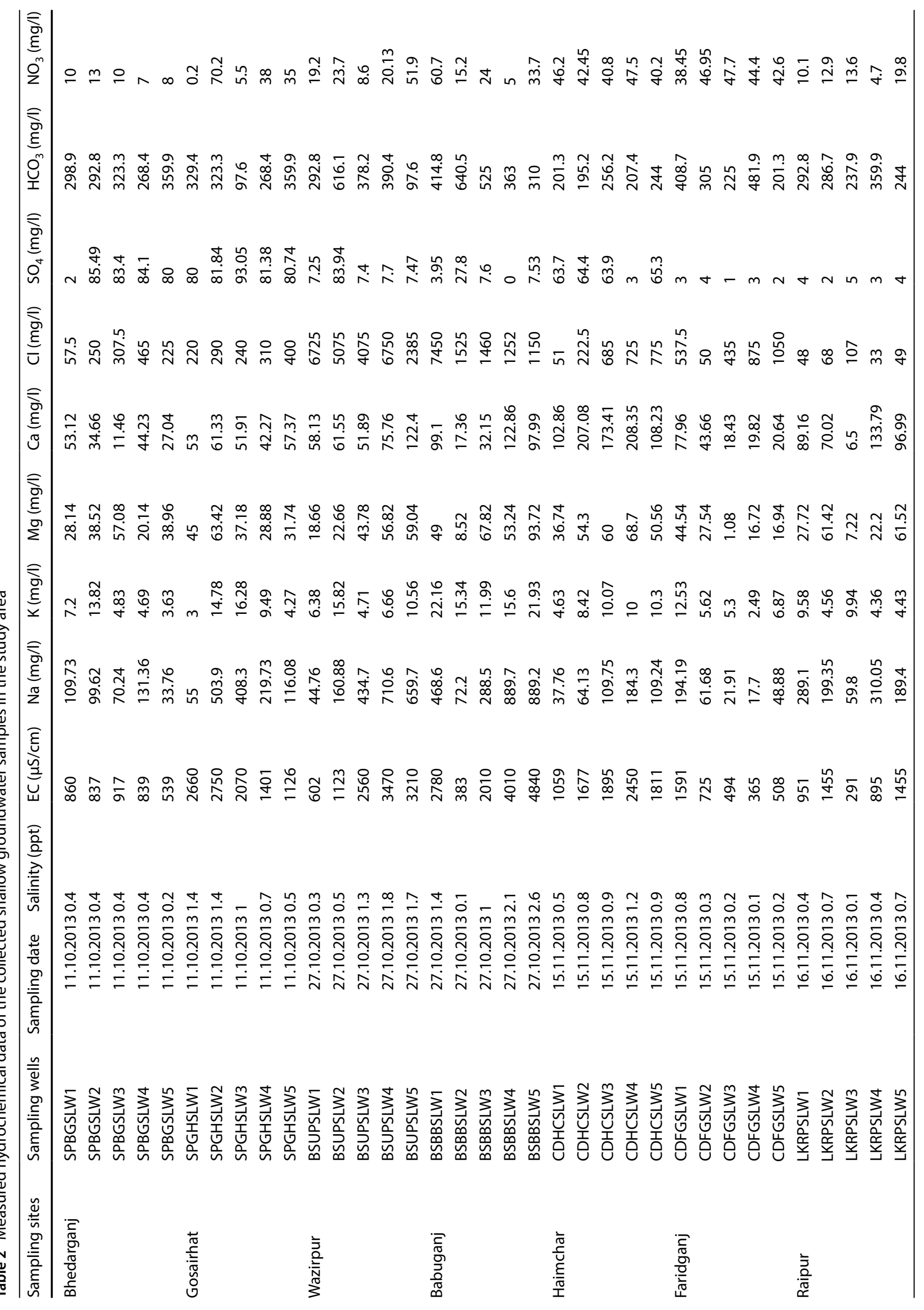




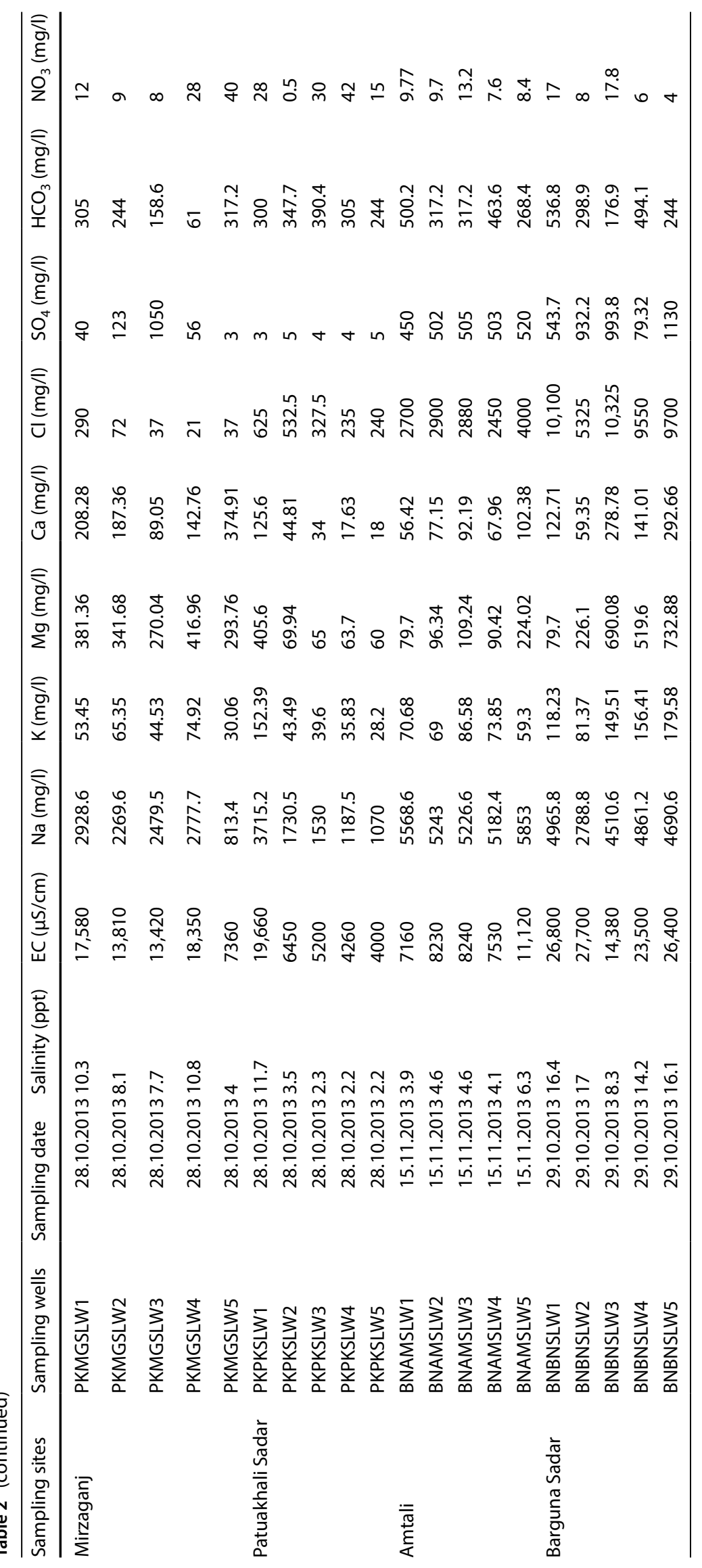

SN Applied Sciences

A SPRINGER NATURE journal 


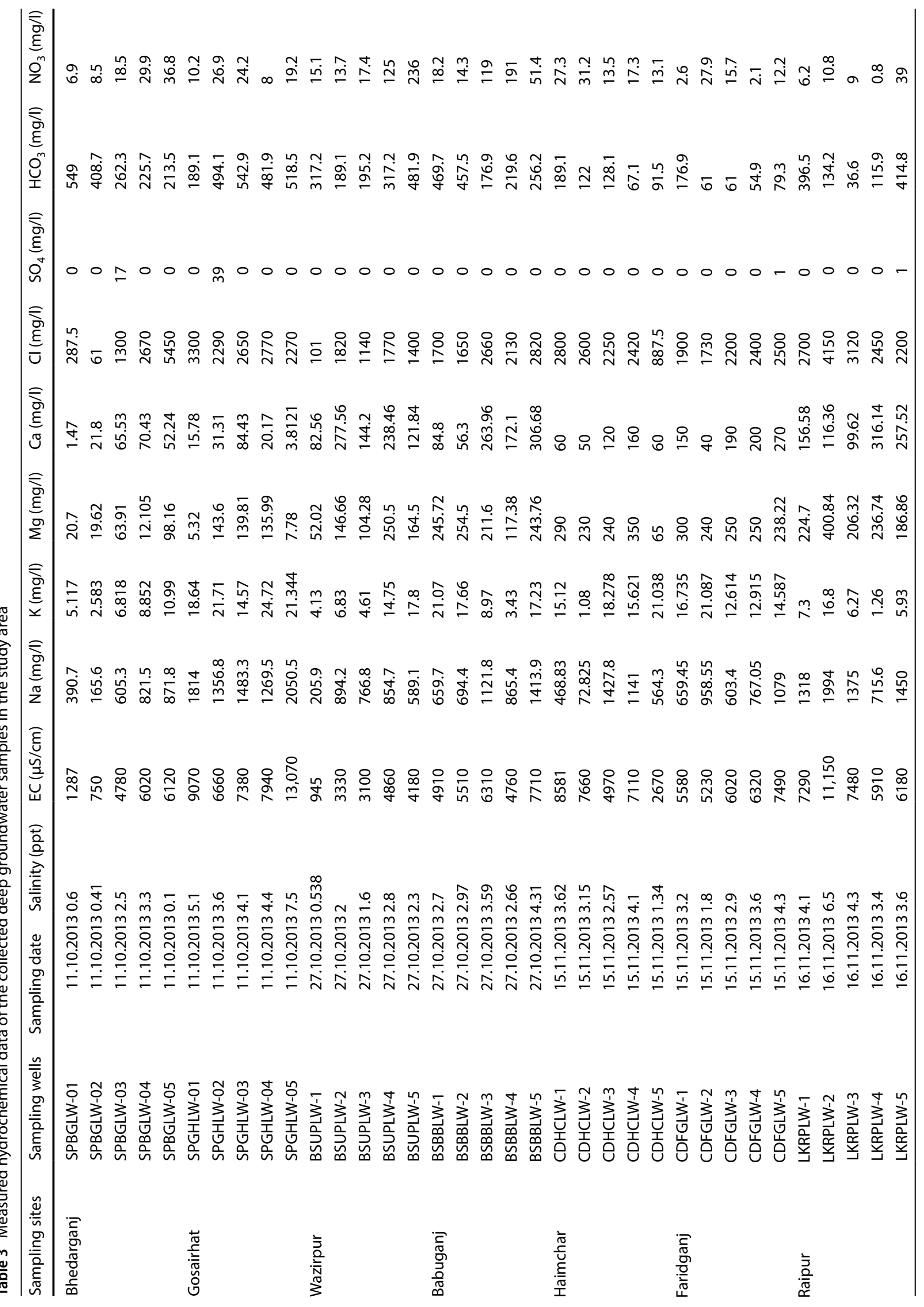




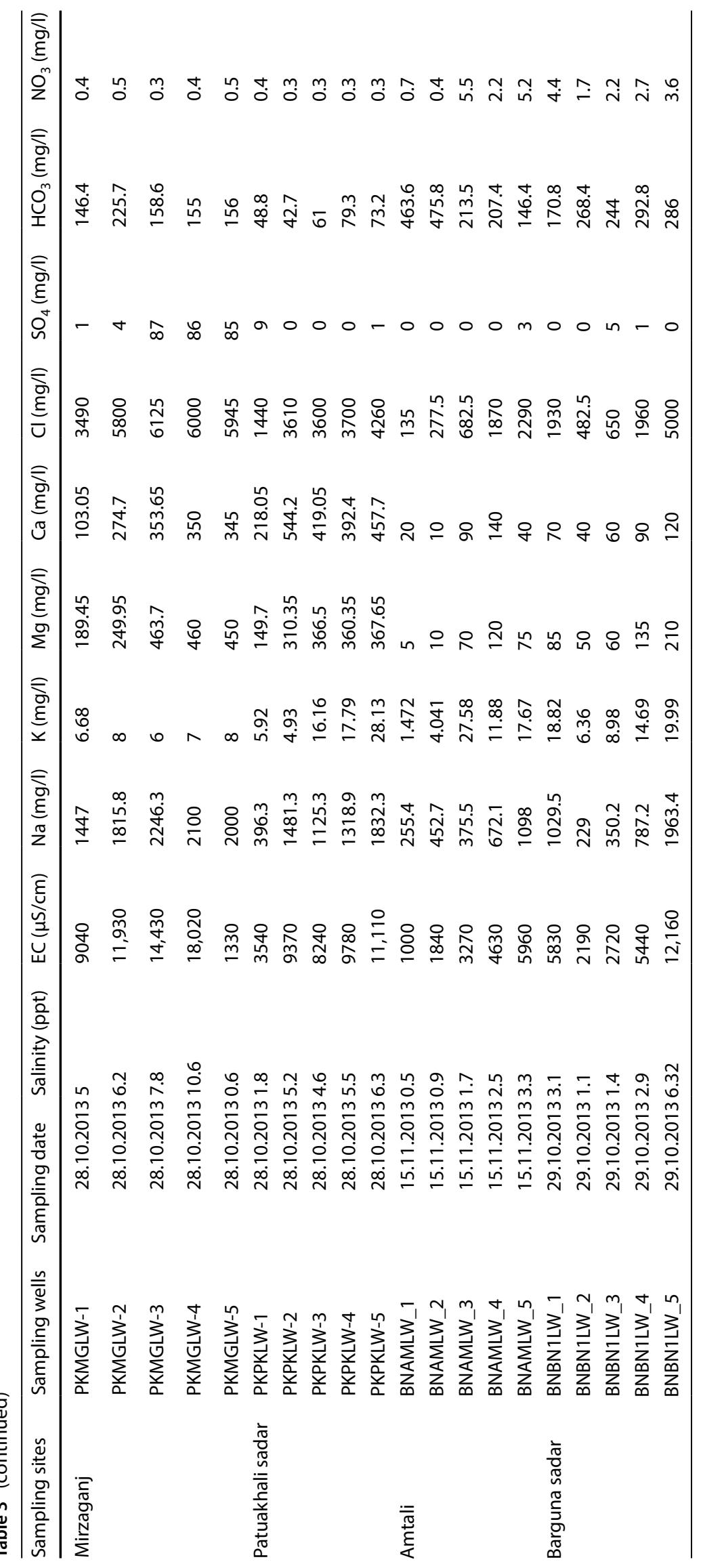

SN Applied Sciences

A SPRINGER NATURE journal 
tide and high tide effects are responsible for differences in salinity values. $\mathrm{Mg}^{2+}$ and $\mathrm{HCO}_{3}{ }^{-}$ions are dominant in river water with an average concentration of 37.41 percent of the total cation and 43.20 percent of the total anion, respectively. The shallow and deep groundwater have excess levels of $\mathrm{Na}^{+}, \mathrm{K}^{+}$and $\mathrm{Cl}^{-}$ions; where the average concentrations of $\mathrm{Na}^{+}+\mathrm{K}^{+}$and $\mathrm{Cl}^{-}$ions in shallow groundwater are 63.84 percent and 63.61 percent of the total cations and anions, respectively. Deep groundwater is very highly concentrated by $\mathrm{Na}^{+}+\mathrm{K}^{+}$and $\mathrm{Cl}^{-}$ion, with an average of $66.27 \%$ of total cations and $88.25 \%$ of total anions, respectively. Excessive concentrations of $\mathrm{Na}^{+}, \mathrm{K}^{+}$ and $\mathrm{Cl}^{-}$ions lead to seawater contamination in groundwater, and $\mathrm{HCO}_{3}{ }^{-}$along with $\mathrm{Na}^{+}, \mathrm{Ca}^{2+}, \mathrm{Mg}^{2+}$ in river water suggest a mixture of freshwater and seawater.

Hydrochemistry of river water and groundwater has been characterized by hydrochemical classification of waters. Hydrochemical water types, phases and facies were categorized among three sources by plotting major cations and anions using piper diagrams and HFE-D diagrams. According to Arthur M. Piper [14], Groundwater can be classified into 6 types occurring in 6 fields in the Piper diagram. These fields are 1. $\mathrm{Ca}-\mathrm{HCO}_{3}$ type 2. $\mathrm{Na}-\mathrm{Cl}$ type 3 . $\mathrm{Ca}-\mathrm{Mg}-\mathrm{Cl}$ type, 4.Ca-Na-HCO type 5 . $\mathrm{Ca}-\mathrm{Cl}$ type and 6 . $\mathrm{Na}-\mathrm{HCO}_{3}$ type. In some cases, $\mathrm{Mg}^{2+}$ replaces the $\mathrm{Ca}^{2+}$ and forms the $\mathrm{Mg}-\mathrm{HCO}_{3}$ water type. Freshening and intrusion phases denote the direct cation exchange and reverse cation exchange, respectively. In HFE-D diagram freshening phase points are placed on the left of the mixing line and intrusion phase points are placed on the right of the mixing line [13]. The term facies is measured relative to the percentage of $\mathrm{Ca}^{2+}$ and $\mathrm{Na}^{+}$cations, and $\mathrm{HCO}_{3}{ }^{-}$(or $\mathrm{SO}_{4}{ }^{2+}$ ) and $\mathrm{Cl}^{-}$anions in regards to the sum of cations and anions, respectively. The facies are recognized using the term Mix to indicate that the percentage of cation or anion is less than $50 \%$. There are four major facies in HFE-D: $\mathrm{NaCl}, \mathrm{CaCl}$, $\mathrm{Na}-\mathrm{HCO}_{3}$, and $\mathrm{Ca}-\mathrm{HCO}_{3}$. And each major facies also comprise four other facies that are related to it [15]. Detailed hydrochemical facies and phases of water are shown in Tables 4 and 5 illustrating the phases and facies among three sources of water.

The Piper diagram of river water indicates the dissimilar water types. The seventeen river water samples lie on four quadrants $(1,2,3$ and 5$)$ of the Piper diagram, where about $60 \%$ samples are $\mathrm{Ca}-\mathrm{HCO} 3$ type, about $30 \%$ are $\mathrm{Ca}-\mathrm{Mg}-\mathrm{Cl}$ type and about $10 \%$ are $\mathrm{Na}-\mathrm{Cl}$ and $\mathrm{Ca}-\mathrm{Cl}$ types (Fig. 4a). This dissimilarity clearly indicates mixing of different sources water. The percentage trends of cations in river water are $\mathrm{Mg}^{2+}>\mathrm{Na}^{+}+\mathrm{K}^{+}>\mathrm{Ca}^{2+}$ and $\mathrm{HCO}_{3}{ }^{-}>\mathrm{Cl}^{-}>\mathrm{SO}_{4}{ }^{2-}$ for anion. It is assumed that the percentage of $\mathrm{Mg}^{2+}$ ion is greater than of $\mathrm{Ca}^{2+}$ and $\mathrm{Na}^{+}$which may indicate dissolved clay sediments in the river water. HFE-D diagram suggests that the most samples are characterized by freshening
Table 4 Freshening-intrusion phases and hydrochemical facies of different river water samples

\begin{tabular}{llll}
\hline River water sampling stations & Phases & $\begin{array}{l}\text { Hydrochemical } \\
\text { facies }\end{array}$ \\
\hline Haimchar (Meghna) & Freshening & $\mathrm{Ca}$ & $\mathrm{HCO}_{3}$ \\
Ramgati (Meghna) & Freshening & $\mathrm{MixCa}$ & $\mathrm{HCO}_{3}$ \\
Gaurnadi (Arial Kha) & Freshening & MixMg & $\mathrm{HCO}_{3}$ \\
Muladi (Naya Vangani) & Freshening & $\mathrm{MixMg}$ & $\mathrm{HCO}_{3}$ \\
Wazirpur (Sikarpur) & Freshening & $\mathrm{Mg}$ & $\mathrm{HCO}_{3}$ \\
Babuganj (Sandha) & Intrusion & $\mathrm{Mg}$ & $\mathrm{HCO}_{3}$ \\
Nalcity (Dhanshiri) & Freshening & $\mathrm{MixMg}$ & $\mathrm{HCO}_{3}$ \\
Bakerganj (Karkhana) & Freshening & $\mathrm{Mg}$ & $\mathrm{HCO}_{3}$ \\
Jhalokathi sadar (Gab Khan) & Freshening & $\mathrm{Ca}$ & $\mathrm{HCO}_{3}$ \\
Patuakhali sadar (Payra) & Freshening & $\mathrm{MixNa}$ & $\mathrm{Cl}^{\prime}$ \\
Mirzaganj (Payra) & Freshening & $\mathrm{MixNa}$ & $\mathrm{MixCl}$ \\
Amtali (Payra) & Freshening & $\mathrm{Na}$ & $\mathrm{MixCl}$ \\
Barguna sadar (Payra) & Intrusion & $\mathrm{Mg}$ & $\mathrm{Cl}$ \\
Barguna sadar (Bishkhali) & Freshening & $\mathrm{MixNa}$ & $\mathrm{MixHCO}$ \\
Betagi (Bishkhali) & Freshening & $\mathrm{MixNa}$ & $\mathrm{HCO}$ \\
Dasmina (Tentulia) & Freshening & $\mathrm{Na}$ & $\mathrm{Cl}$ \\
Kalapara (Andharmanik) & Intrusion & $\mathrm{Na}$ & $\mathrm{Cl}$ \\
\hline
\end{tabular}

phases indicating recharge or mixing freshwater into river water except three samples (Fig. 4b). Among sixteen facies, there are eleven hydrochemical facies have been recognized where about $82 \%$ facies are characterized by freshening phases and $18 \%$ by intrusion phases (Table 4 ). More than $60 \%$ river water samples lie on $\mathrm{Ca}-\mathrm{HCO}_{3}$ (or, $\mathrm{Mg}-\mathrm{HCO}_{3}$ ) facies quadrant of HFE-D diagram. The facies number of river water are relatively wide than groundwater may imply recharge of freshwater in the existing water and show intermediate stage facies recognized by mixing ions.

Nitrate $\left(\mathrm{NO}_{3}{ }^{-}\right)$concentrations ranging from 0.0956 to $6.953 \mathrm{mg} / \mathrm{l}$ indicate a negligible to low concentration in river water samples (Table 1). Denitrification, regular interval tidal activity and river current in the coastal area cause a very low concentration of nitrate in river water.

Table 5 shows detail of hydrochemical phases and facies of all groundwater samples collected from two different depths. There are five quadrants (1,2,3,4 and 5) exhibit the shallow groundwater samples plotting on the Piper diagram, where more than $70 \%$ samples are $\mathrm{Na}-\mathrm{Cl}$ types and other types are $\mathrm{Ca}-\mathrm{Na}-\mathrm{HCO}_{3}, \mathrm{Ca}-\mathrm{Mg}-\mathrm{Cl}, \mathrm{Ca}-\mathrm{Cl}$ and $\mathrm{Na}-\mathrm{HCO}_{3}$ (Fig. 5a). This plotting suggests that alkali earths exceed alkaline earths; and strong acids exceed weak acids in shallow groundwater. The trends of ions concentration in shallow groundwater are $\mathrm{Cl}^{-}>\mathrm{HCO}_{3}{ }^{-}>\mathrm{SO}_{4}{ }^{2-}$ for anion and $\mathrm{Na}^{+}+\mathrm{K}^{+}>\mathrm{Mg}^{2+}>\mathrm{Ca}^{2+}$ for cation.

Hydrochemical facies evaluation (HFE-D) diagram (Fig. 5b) of shallow groundwater samples notices that 
Table 5 Hydrochemical facies and freshening-intrusion phases of the two depths groundwater samples

\begin{tabular}{|c|c|c|c|c|c|c|c|c|}
\hline \multirow{3}{*}{$\begin{array}{l}\text { Sampling sites } \\
\text { Bhedarganj }\end{array}$} & \multicolumn{4}{|c|}{ Shallow groundwater } & \multicolumn{4}{|c|}{ Deep groundwater } \\
\hline & \multirow{2}{*}{$\begin{array}{l}\text { Sampling wells } \\
\text { SPBGSLW1 }\end{array}$} & \multirow{2}{*}{$\begin{array}{l}\text { Phases } \\
\text { Freshening }\end{array}$} & \multicolumn{2}{|c|}{ Hydrochemical facies } & \multirow{2}{*}{$\begin{array}{l}\text { Sampling wells } \\
\text { SPBGLW-01 }\end{array}$} & \multirow{2}{*}{$\begin{array}{l}\text { Phases } \\
\text { Freshening }\end{array}$} & \multicolumn{2}{|c|}{$\begin{array}{l}\text { Hydrochemical } \\
\text { facies }\end{array}$} \\
\hline & & & $\mathrm{MixNa}$ & $\mathrm{HCO}_{3}$ & & & $\mathrm{Na}$ & $\mathrm{HCO}_{3}$ \\
\hline & SPBGSLW2 & Intrusion & $\mathrm{MixNa}$ & $\mathrm{Cl}$ & SPBGLW-02 & Freshening & $\mathrm{Na}$ & $\mathrm{HCO}_{3}$ \\
\hline & SPBGSLW3 & Intrusion & $\mathrm{Mg}$ & $\mathrm{Cl}$ & SPBGLW-03 & Intrusion & $\mathrm{Na}$ & $\mathrm{Cl}$ \\
\hline & SPBGSLW4 & Intrusion & $\mathrm{Na}$ & $\mathrm{Cl}$ & SPBGLW-04 & Freshening & $\mathrm{Na}$ & $\mathrm{Cl}$ \\
\hline & SPBGSLW5 & Intrusion & $\mathrm{Mg}$ & $\mathrm{MixCl}$ & SPBGLW-05 & Intrusion & $\mathrm{Na}$ & $\mathrm{Cl}$ \\
\hline \multirow[t]{5}{*}{ Gosairhat } & SPGHSLW1 & Intrusion & MixMg & $\mathrm{MixCl}$ & SPGHLW-01 & Freshening & $\mathrm{Na}$ & $\mathrm{Cl}$ \\
\hline & SPGHSLW2 & Freshening & $\mathrm{Na}$ & $\mathrm{Cl}$ & SPGHLW-02 & Freshening & $\mathrm{Na}$ & $\mathrm{Cl}$ \\
\hline & SPGHSLW3 & Freshening & $\mathrm{Na}$ & $\mathrm{Cl}$ & SPGHLW-03 & Freshening & $\mathrm{Na}$ & $\mathrm{Cl}$ \\
\hline & SPGHSLW4 & Freshening & $\mathrm{Na}$ & $\mathrm{Cl}$ & SPGHLW-04 & Freshening & $\mathrm{Na}$ & $\mathrm{Cl}$ \\
\hline & SPGHSLW5 & Intrusion & $\mathrm{MixNa}$ & $\mathrm{Cl}$ & SPGHLW-05 & Freshening & $\mathrm{Na}$ & $\mathrm{Cl}$ \\
\hline \multirow[t]{5}{*}{ Wazirpur } & BSUPSLW1 & Intrusion & $\mathrm{MixCa}$ & $\mathrm{Cl}$ & BSUPLW-1 & Freshening & $\mathrm{Na}$ & $\mathrm{HCO}_{3}$ \\
\hline & BSUPSLW2 & Intrusion & $\mathrm{Na}$ & $\mathrm{Cl}$ & BSUPLW-2 & Intrusion & $\mathrm{Na}$ & $\mathrm{Cl}$ \\
\hline & BSUPSLW3 & Intrusion & $\mathrm{Na}$ & $\mathrm{Cl}$ & BSUPLW-3 & Intrusion & $\mathrm{Na}$ & $\mathrm{Cl}$ \\
\hline & BSUPSLW4 & Intrusion & $\mathrm{Na}$ & $\mathrm{Cl}$ & BSUPLW-4 & Intrusion & $\mathrm{Na}$ & $\mathrm{Cl}$ \\
\hline & BSUPSLW5 & Intrusion & $\mathrm{Na}$ & $\mathrm{Cl}$ & BSUPLW-5 & Intrusion & $\mathrm{Na}$ & $\mathrm{Cl}$ \\
\hline \multirow[t]{5}{*}{ Babuganj } & BSBBSLW1 & Intrusion & $\mathrm{Na}$ & $\mathrm{Cl}$ & BSBBLW-1 & Intrusion & $\mathrm{Na}$ & $\mathrm{Cl}$ \\
\hline & BSBBSLW2 & Intrusion & $\mathrm{Na}$ & $\mathrm{Cl}$ & BSBBLW-2 & Intrusion & $\mathrm{Na}$ & $\mathrm{Cl}$ \\
\hline & BSBBSLW3 & Intrusion & $\mathrm{Na}$ & $\mathrm{Cl}$ & BSBBLW-3 & Intrusion & $\mathrm{Na}$ & $\mathrm{Cl}$ \\
\hline & BSBBSLW4 & Freshening & $\mathrm{Na}$ & $\mathrm{Cl}$ & BSBBLW-4 & Intrusion & $\mathrm{Na}$ & $\mathrm{Cl}$ \\
\hline & BSBBSLW5 & Freshening & $\mathrm{Na}$ & $\mathrm{Cl}$ & BSBBLW-5 & Intrusion & $\mathrm{Na}$ & $\mathrm{Cl}$ \\
\hline \multirow[t]{5}{*}{ Haimchar } & CDHCSLW1 & Intrusion & $\mathrm{Ca}$ & $\mathrm{MixHCO}_{3}$ & CDHCLW-1 & Intrusion & MixNa & $\mathrm{Cl}$ \\
\hline & CDHCSLW2 & Intrusion & $\mathrm{Ca}$ & $\mathrm{Cl}$ & CDHCLW-2 & Intrusion & $\mathrm{Na}$ & $\mathrm{Cl}$ \\
\hline & CDHCSLW3 & Intrusion & $\mathrm{MixCa}$ & $\mathrm{Cl}$ & CDHCLW-3 & Intrusion & MixNa & $\mathrm{Cl}$ \\
\hline & CDHCSLW4 & Intrusion & $\mathrm{MixCa}$ & $\mathrm{Cl}$ & CDHCLW-4 & Intrusion & $\mathrm{Na}$ & $\mathrm{Cl}$ \\
\hline & CDHCSLW5 & Intrusion & $\mathrm{MixCa}$ & $\mathrm{Cl}$ & CDHCLW-5 & Intrusion & $\mathrm{Na}$ & $\mathrm{Cl}$ \\
\hline \multirow[t]{5}{*}{ Faridganj } & CDFGSLW1 & Intrusion & $\mathrm{Na}$ & $\mathrm{Cl}$ & CDFGLW-1 & Intrusion & $\mathrm{Na}$ & $\mathrm{Cl}$ \\
\hline & CDFGSLW2 & Freshening & MixNa & $\mathrm{HCO}_{3}$ & CDFGLW-2 & Intrusion & $\mathrm{Na}$ & $\mathrm{Cl}$ \\
\hline & CDFGSLW3 & Intrusion & $\mathrm{Na}$ & $\mathrm{Cl}$ & CDFGLW-3 & Intrusion & $\mathrm{Na}$ & $\mathrm{Cl}$ \\
\hline & CDFGSLW4 & Intrusion & MixMg & $\mathrm{Cl}$ & CDFGLW-4 & Intrusion & $\mathrm{Na}$ & $\mathrm{Cl}$ \\
\hline & CDFGSLW5 & Intrusion & $\mathrm{MixNa}$ & $\mathrm{Cl}$ & CDFGLW-5 & Intrusion & $\mathrm{Na}$ & $\mathrm{Cl}$ \\
\hline \multirow[t]{5}{*}{ Raipur } & LKRPSLW1 & Freshening & $\mathrm{Na}$ & $\mathrm{HCO}_{3}$ & LKRPLW-1 & Intrusion & MixNa & $\mathrm{Cl}$ \\
\hline & LKRPSLW2 & Freshening & $\mathrm{Na}$ & $\mathrm{HCO}_{3}$ & LKRPLW-2 & Intrusion & $\mathrm{Na}$ & $\mathrm{Cl}$ \\
\hline & LKRPSLW3 & Freshening & $\mathrm{Na}$ & $\mathrm{HCO}_{3}$ & LKRPLW-3 & Intrusion & $\mathrm{MixNa}$ & $\mathrm{Cl}$ \\
\hline & LKRPSLW4 & Freshening & $\mathrm{Na}$ & $\mathrm{HCO}_{3}$ & LKRPLW-4 & Intrusion & $\mathrm{Na}$ & $\mathrm{Cl}$ \\
\hline & LKRPSLW5 & Freshening & $\mathrm{MixNa}$ & $\mathrm{HCO}_{3}$ & LKRPLW-5 & Intrusion & $\mathrm{Na}$ & $\mathrm{Cl}$ \\
\hline \multirow[t]{5}{*}{ Mirzaganj } & PKMGSLW1 & Freshening & $\mathrm{Na}$ & $\mathrm{Cl}$ & PKMGLW-1 & Intrusion & $\mathrm{Na}$ & $\mathrm{Cl}$ \\
\hline & PKMGSLW2 & Freshening & $\mathrm{Na}$ & $\mathrm{MixHCO}_{3}$ & PKMGLW-2 & Intrusion & $\mathrm{Na}$ & $\mathrm{Cl}$ \\
\hline & PKMGSLW3 & Freshening & $\mathrm{Na}$ & $\mathrm{SO}_{4}$ & PKMGLW-3 & Intrusion & $\mathrm{Na}$ & $\mathrm{Cl}$ \\
\hline & PKMGSLW4 & Freshening & $\mathrm{Na}$ & $\mathrm{MixSO}_{4}$ & PKMGLW-4 & Intrusion & $\mathrm{MixNa}$ & $\mathrm{Cl}$ \\
\hline & PKMGSLW5 & Freshening & $\mathrm{MixNa}$ & $\mathrm{HCO}_{3}$ & PKMGLW-5 & Intrusion & $\mathrm{Na}$ & $\mathrm{Cl}$ \\
\hline \multirow[t]{5}{*}{ Patuakhali sadar } & PKPKSLW1 & Freshening & $\mathrm{Na}$ & $\mathrm{Cl}$ & PKPKLW-1 & Intrusion & $\mathrm{Mg}$ & $\mathrm{Cl}$ \\
\hline & PKPKSLW2 & Freshening & $\mathrm{Na}$ & $\mathrm{Cl}$ & PKPKLW-2 & Intrusion & $\mathrm{Mg}$ & $\mathrm{Cl}$ \\
\hline & PKPKSLW3 & Freshening & $\mathrm{Na}$ & $\mathrm{Cl}$ & PKPKLW-3 & Intrusion & $\mathrm{Na}$ & $\mathrm{Cl}$ \\
\hline & PKPKSLW4 & Freshening & $\mathrm{Na}$ & $\mathrm{Cl}$ & PKPKLW-4 & Intrusion & $\mathrm{Na}$ & $\mathrm{Cl}$ \\
\hline & PKPKSLW5 & Freshening & $\mathrm{Na}$ & $\mathrm{Cl}$ & PKPKLW-5 & Intrusion & $\mathrm{Na}$ & $\mathrm{Cl}$ \\
\hline
\end{tabular}


Table 5 (continued)

\begin{tabular}{|c|c|c|c|c|c|c|c|c|}
\hline \multirow{3}{*}{$\begin{array}{l}\text { Sampling sites } \\
\text { Amtali }\end{array}$} & \multicolumn{4}{|c|}{ Shallow groundwater } & \multicolumn{4}{|c|}{ Deep groundwater } \\
\hline & \multirow{2}{*}{$\begin{array}{l}\text { Sampling wells } \\
\text { BNAMSLW1 }\end{array}$} & \multirow{2}{*}{$\begin{array}{l}\text { Phases } \\
\text { Freshening }\end{array}$} & \multicolumn{2}{|c|}{ Hydrochemical facies } & \multirow{2}{*}{$\begin{array}{l}\text { Sampling wells } \\
\text { BNAMLW_1 }\end{array}$} & \multirow{2}{*}{$\begin{array}{l}\text { Phases } \\
\text { Freshening }\end{array}$} & \multicolumn{2}{|c|}{$\begin{array}{l}\text { Hydrochemical } \\
\text { facies }\end{array}$} \\
\hline & & & $\mathrm{Na}$ & $\mathrm{Cl}$ & & & $\mathrm{Na}$ & $\mathrm{HCO}_{3}$ \\
\hline & BNAMSLW2 & Freshening & $\mathrm{Na}$ & $\mathrm{Cl}$ & BNAMLW_2 & Freshening & $\mathrm{Na}$ & $\mathrm{Cl}$ \\
\hline & BNAMSLW3 & Freshening & $\mathrm{Na}$ & $\mathrm{Cl}$ & BNAMLW_3 & Intrusion & $\mathrm{Na}$ & $\mathrm{Cl}$ \\
\hline & BNAMSLW4 & Freshening & $\mathrm{Na}$ & $\mathrm{Cl}$ & BNAMLW_4 & Intrusion & $\mathrm{Na}$ & $\mathrm{Cl}$ \\
\hline & BNAMSLW5 & Freshening & $\mathrm{Na}$ & $\mathrm{Cl}$ & BNAMLW_5 & Freshening & $\mathrm{Na}$ & $\mathrm{Cl}$ \\
\hline \multirow[t]{5}{*}{ Barguna sadar } & BNBNSLW1 & Freshening & $\mathrm{Na}$ & $\mathrm{Cl}$ & BNBN1LW_1 & Intrusion & $\mathrm{Na}$ & $\mathrm{Cl}$ \\
\hline & BNBNSLW2 & Freshening & $\mathrm{Na}$ & $\mathrm{Cl}$ & BNBN1LW_2 & Intrusion & $\mathrm{Na}$ & $\mathrm{Cl}$ \\
\hline & BNBNSLW3 & Intrusion & $\mathrm{Na}$ & $\mathrm{Cl}$ & BNBN1LW_3 & Intrusion & $\mathrm{Na}$ & $\mathrm{Cl}$ \\
\hline & BNBNSLW4 & Intrusion & $\mathrm{Na}$ & $\mathrm{Cl}$ & BNBN1LW_4 & Intrusion & $\mathrm{Na}$ & $\mathrm{Cl}$ \\
\hline & BNBNSLW5 & Intrusion & $\mathrm{Na}$ & $\mathrm{Cl}$ & BNBN1LW_5 & Intrusion & $\mathrm{Na}$ & $\mathrm{Cl}$ \\
\hline
\end{tabular}

there are fourteen facies exist and characterized by $53 \%$ freshening phases and $47 \%$ by intrusion phases (Table 5 ). Shallow groundwater types and facies for individual sites along shallow wells are of a dissimilar nature: considering the first shallow well nearest to the river, six wells are affected by freshening phases and five other sites are affected by intrusion phases. Six sites whose first well are recognized by freshening phases are Bhedarganj, Raipur, Mirzaganj, Patuakhali Sadar, Amtali and Barguna Sadar. These wells may be influenced either by freshwater or rainwater or by direct cation exchange with aquifer sediments.

More than 70 percent of the shallow groundwater samples are found on the $\mathrm{Na}-\mathrm{Cl}$ quadrant facies of the HFE-D diagram. The intrusion of seawater into shallow aquifers and the mixing of fresh groundwater with seawater are prominent from HFE-D, which is clearly seen from the $\mathrm{Na}-\mathrm{Cl}$ facies quadrant in which both intrusion and freshening phases are characterized by $\mathrm{Na}-\mathrm{Cl}$.

Five other shallow well locations at: Gosairhat, Wazirpur, Babuganj, Haimchar and Faridganj, whose first wells (nearest to river) are experienced by intrusion phases. Several causes may be responsible for the hydrochemical phase variation among the wells in the different locations. These variations may be due to either lithology of aquifers or tidal activity or percolation of rain water. Overall it is said that the shallow groundwater of the study area are interacted to river water as well as to seawater.

Nitrate contamination in shallow groundwater is moderate to high; and both the lowest and highest values found in Gosairhat; $0.2 \mathrm{mg} / \mathrm{l}$ at the first well and $70.2 \mathrm{mg} / \mathrm{l}$ at the second well near the river, respectively (Table 2 ). Most shallow groundwater samples exceed the Bangladesh standard of nitrate $(10 \mathrm{mg} / \mathrm{l})$, indicating shallow aquifers of the coastal area are influenced by anthropogenic activities.
Deep Groundwater chemistry on piper plot (Fig. 6a) specifically indicates the dominant $\mathrm{Na}-\mathrm{Cl}$ type of water in the study area. Almost 95\% deep groundwater samples lie on the $\mathrm{Na}-\mathrm{Cl}$ type fields of the piper diagram (Fig. 6a). In this case, alkali earths exceed alkaline earths; and strong acids exceed weak acids in deep groundwater. lons concentration trends in deep groundwater are $\mathrm{Cl}^{-}>\mathrm{HCO}_{3}^{-}>\mathrm{SO}_{4}{ }^{2-}$ for anion and $\mathrm{Na}^{+}+\mathrm{K}^{+}>\mathrm{Mg}^{2+}>\mathrm{Ca}^{2+}$ for cation. HFE-D diagram for deep groundwater reveals that there only four hydrochemical facies are identified, and $78 \%$ corresponding to intrusion phases and $22 \%$ to freshening phases (Fig. $6 \mathrm{~b}$ and Table 5). All deep groundwater samples except six lie in the $\mathrm{Na}-\mathrm{Cl}$ substages of the HFE-D diagram. Approximately more than $95 \%$ of the deep ground water samples lie on the $\mathrm{Na}-\mathrm{Cl}$ facies quadrant and the maximum is characterized by intrusion phases.

The deep groundwater with dominant $\mathrm{Na}-\mathrm{Cl}$ indicates the presence of sea or brine water. Concentrations of $\mathrm{Ca}$ decrease, while the concentrations of $\mathrm{Na}$ increase in deep groundwater which may indicate the reverse ion exchange process between aquifer and saline water. This also could be due to mixing of shallow groundwater to deep groundwater.

Groundwater types and facies for individual sites along deep wells are of two natures: considering the first shallow well closest to the river, the first four wells of four sites are affected by refreshing phases and seven wells from other sites are affected by intrusion phases. Most wells are affected by intrusion phases and intrusion of seawater may be the main cause of this condition. Deep aquifer of the coastal region potentially interconnected with seawater.

$\mathrm{Ca}, \mathrm{Mg}$, and $\mathrm{HCO}_{3}$ are the most abundant ions in natural waters, while $\mathrm{Na}$ and $\mathrm{Cl}$ provide an indicator of the deposition and dissolution of halite from hydrologically derived $\mathrm{Na}-\mathrm{Cl}$ ions in areas along the coast. In addition, 
Fig. 4 a Piper diagram shows the river water types; $\mathbf{b}$ HFE-D diagram depicts the freshening-intrusion phases of river water samples in the coastal delta of Bangladesh (a)

River Water Chemistry

Water Type Fields
1. $\mathrm{Ca}-\mathrm{HCO}$
2. $\mathrm{Na}-\mathrm{Cl}$
3. $\mathrm{Ca}-\mathrm{Mg}-\mathrm{Cl}$
4. $\mathrm{Ca}-\mathrm{Na}-\mathrm{HCO}_{3}$
5. $\mathrm{Ca}-\mathrm{Cl}$
6. $\mathrm{Na}-\mathrm{HCO}$

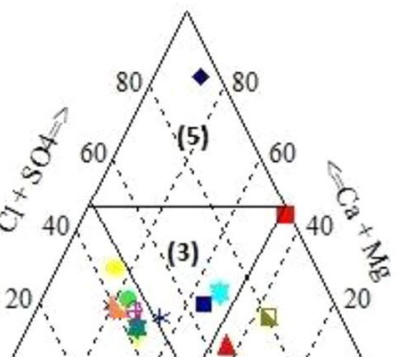

(1) $\because$

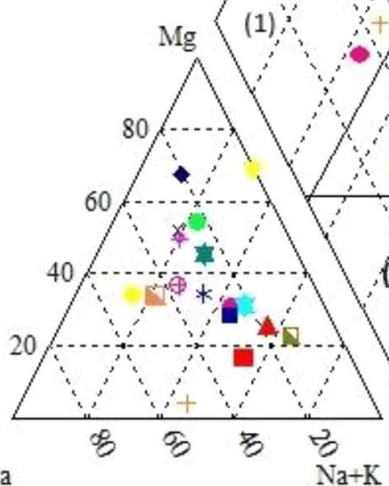

(2)

$\mathrm{SO} 4$
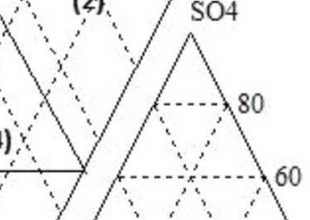

(6)
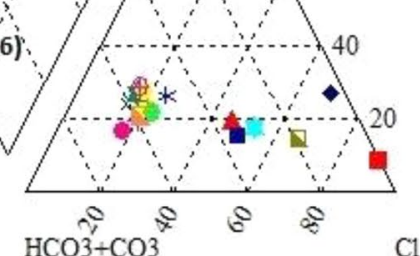

$\mathrm{Cl}$

A Amtali (Payra)

Barguna Sadar (Payra)

- Barguna Sadar (Bishkhali)

- Betagi (Bishkhali)

§ Patuakhali Sadar (Payra)

* Mirzaganj (Payra)

- Babuganj (Sandha)

- Wazirpur (Sikarpur)

+ Haimchar (Meghna)

* Bakerganj (Karkhana)

* Gaurnadi (Arial Kha)

- Ramgati (Meghna)

I. Muladi (Naya Vangani)

+ Nalcity (Dhanshiri)

$\times$ Dasmina (Tentulia)

Jhalokathi Sadar (Gab Khan)

Kalapara (Andharmanik) (b)

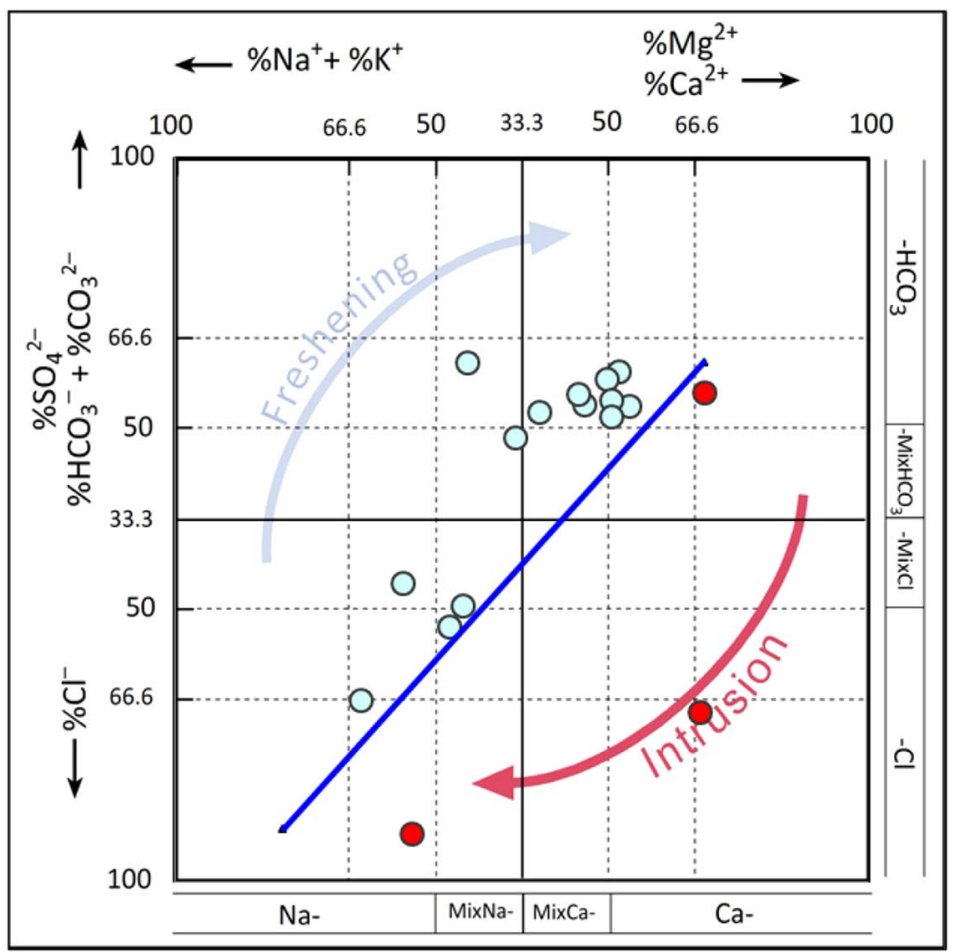

the dominance of $\mathrm{Na}-\mathrm{Cl}$ and $\mathrm{Ca}-\mathrm{Mg}-\mathrm{HCO}_{3}$ water indicates the mixing of new water with ancient/old saline groundwater. The very high positive correlation between $\mathrm{Na}$ and $\mathrm{Cl}$ indicates the dominance of $\mathrm{Na}-\mathrm{Cl}$ rich recharge water from coastal origin $[16,17]$.

Deep aquifers in the southern region are moderately contaminated and the middle to northern portion of the coastal area is very highly contaminated with nitrate (Table 3 ). Some deep groundwater samples show extremely high nitrate levels; $236 \mathrm{mg} / \mathrm{l}$ and $125 \mathrm{mg} / \mathrm{l}$ in Wazirpur; $191 \mathrm{mg} / \mathrm{l}$ and $119 \mathrm{mg} / \mathrm{l}$ in Babuganj. Pronounced nitrate levels in deep aquifers indicate either organic compounds in aquifers or leaching from the upper sedimentary layers. 
Fig. 5 a Piper diagram shows the shallow groundwater types; b HFE-D depicts the freshening-intrusion phases of shallow groundwater samples in the coastal delta of Bangladesh

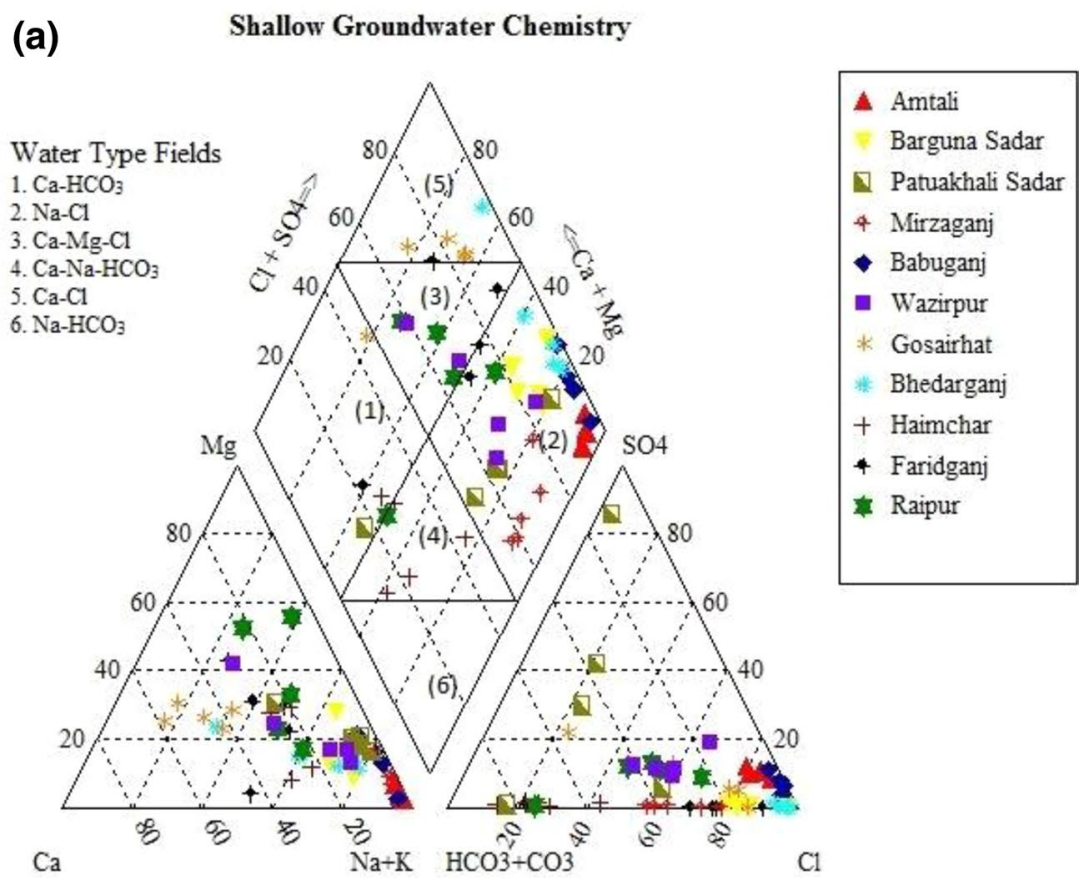

(b)

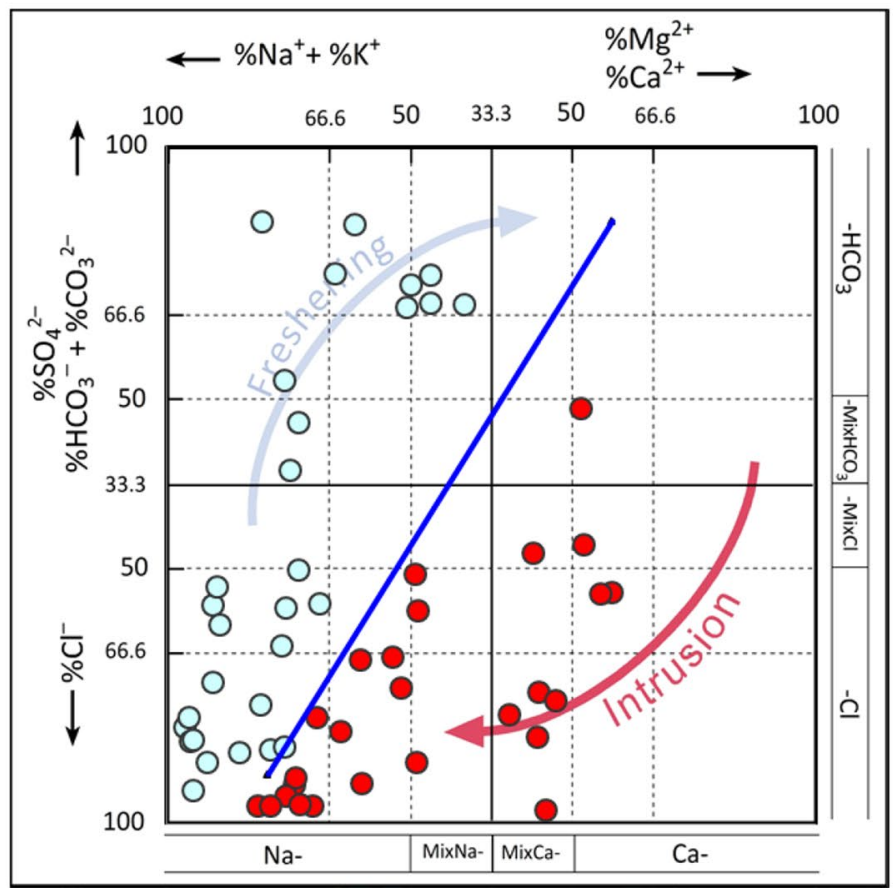

The study area aquifers are mainly recharged from river water, surface runoff and precipitation. The dominance of $\mathrm{Na}-\mathrm{Cl}$ dissolution in both shallow and deep groundwater suggests that there is an input of $\mathrm{Na}-\mathrm{Cl}$ into groundwater from possible sources such as seawater of Bay of Bengal. The study area adjacent to the sea and the dominant nature of sandy-clayey lithology make $\mathrm{NaCl}$ inputs from seawater sources the most relevant.

\subsection{Observations of ion exchange}

Generally, cations and anions are in balance conditions in the most natural waters. When river water or groundwater moves underground, chemical reactions with of its environments tend to develop a chemical balance. Chemical water balance can also be formed through ion exchange. lon exchange involves replacing ions adsorbed on the 
Fig. 6 a Piper diagram shows the deep groundwater types; b HFE-D depicts the freshening-intrusion phases of deep groundwater samples in the coastal delta of Bangladesh

\section{(a)}

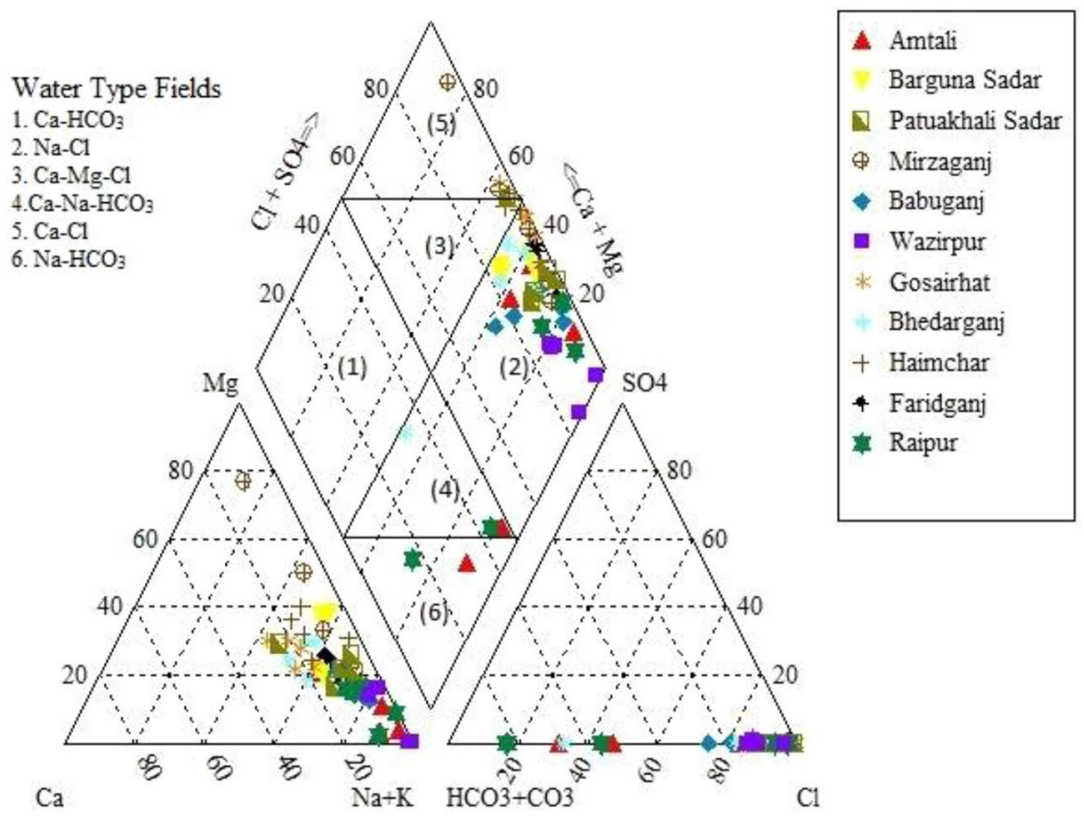

(b)

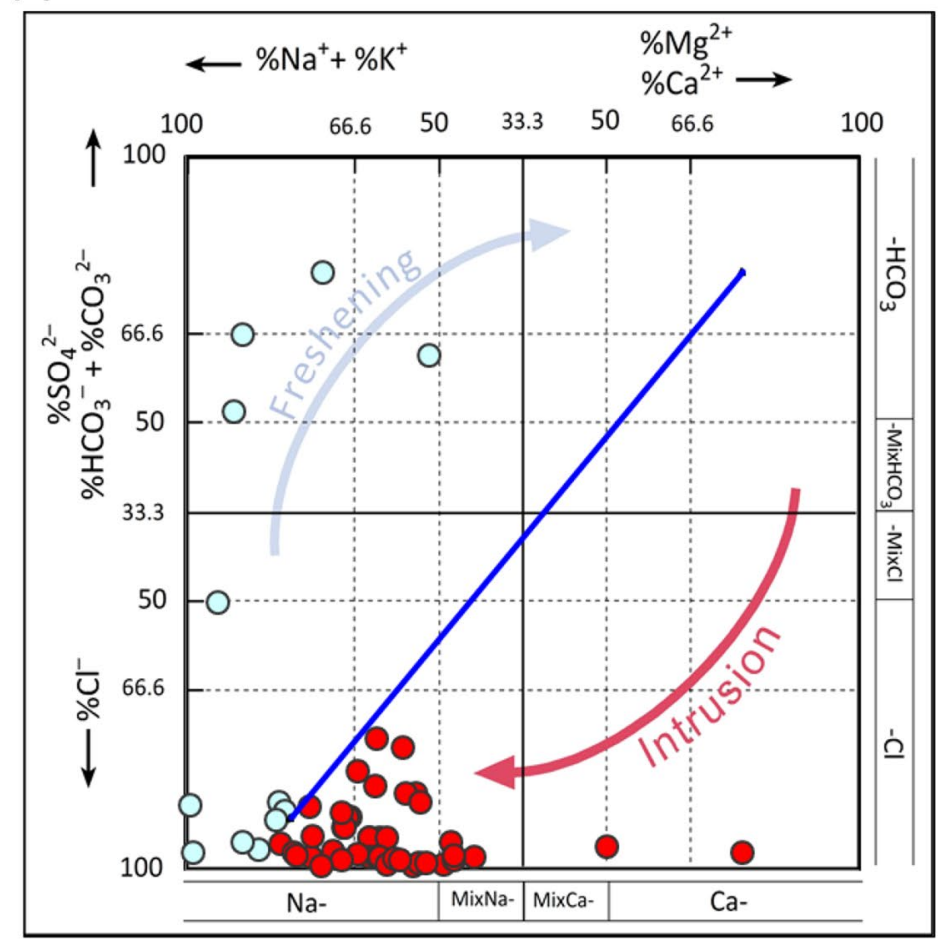

\section{Deep Groundwater Chemistry}

$\mathrm{Cl}$ surface of fine-grained sediments in aquifers with solution ions. Cations $\mathrm{Na}, \mathrm{Ca}$ and $\mathrm{Mg}$ are primarily associated in the exchange. The direction of the exchange is toward the equilibrium of cations present in the water and on the finer sediments of the aquifer [11].

The intrusion and freshening process takes multiple steps. The final facies in intrusion phases are $\mathrm{Na}-\mathrm{Cl}$, which evolves from $\mathrm{Ca}-\mathrm{HCO}_{3}$ facies via the intermediate $\mathrm{Ca}-\mathrm{Cl}$

\section{SN Applied Sciences}

facies. This hydrochemical appearance is characterized by reversing cation exchange reactions. During the freshening process, the $\mathrm{Na}-\mathrm{Cl}$ water was gradually replaced by $\mathrm{Ca}-\mathrm{HCO}_{3}$ water through the intermediate $\mathrm{Na}-\mathrm{HCO}_{3}$ facies or other equivalent facies. When salt water enters a freshwater aquifer, it triggers a reverse cation exchange reaction. The reaction releases $\mathrm{Ca}^{2+}$ ion in previously existing water and $\mathrm{Na}$ ions are adsorbed by aquifer sediments. 
Direct cation exchange occurs during freshening, when the salt water affected aquifer is washed away by presence of fresh calcium bicarbonate water [18].

In this study, HFE-D diagrams facilitate the observation of ion exchange in where four facies $\mathrm{Na}-\mathrm{Cl}, \mathrm{Ca}-\mathrm{Cl}$, $\mathrm{Ca}-\mathrm{HCO}_{3}$ (or, $\mathrm{Mg}-\mathrm{HCO}_{3}$ ) and $\mathrm{Na}-\mathrm{HCO}_{3}$ were considered. The HFE-D diagram for river water demonstrate dominant $\mathrm{Ca}-\mathrm{HCO}_{3}$ and $\mathrm{Mg}-\mathrm{HCO}_{3}$ facies in the central to northern alluvial portion indicating direct cation exchange; and the $\mathrm{Na}-\mathrm{Cl}$ facies in the southern coastal portion denotes reverse cation exchange (Fig. 4b). Shallow groundwater is nearly similarly affected by reverse and direct cation exchange reactions, where deep groundwater is predominantly characterized by reverse cation exchange reactions (Figs. $5 b$ and $6 b$ ). Two end members: the seawater of the Bay of Bengal and the freshwater of the river and aquifer, have participated in mixing visualized in the HFE-D diagram. Dissimilarities in mixing nature of two end members have been observed in river water and groundwater hydrochemistry. In river water HFE-D plotting, the prominent end members are freshwater with respect to seawater and are composed predominantly of $\mathrm{Ca}-\mathrm{HCO}_{3}$ (or $\mathrm{Mg}-\mathrm{HCO}_{3}$ ), where the shallow and deep groundwater is mainly characterized by seawater transgression and comprises the $\mathrm{Na}-\mathrm{Cl}$ composition (Figs. 4, 5 and 6).

\subsection{EC observations between rivers and aquifers}

Electrical conductivity $(E C)$ in both shallow and deep groundwater was observed by measuring the EC value along geodesic distances using a line well position map. Geodesic distances are computed from the river to the line wells in eleven locations where line wells are almost installed across the river (Fig. 1). EC pattern values in two graphs (Fig. 7) have been observed to delineate potential interconnections between river water to shallow groundwater; and shallow to deep groundwater.
Fig. 7 Two graphs showing the comparison of electrical conductivity (EC): a river water to shallow groundwater and (b) river water to deep groundwater

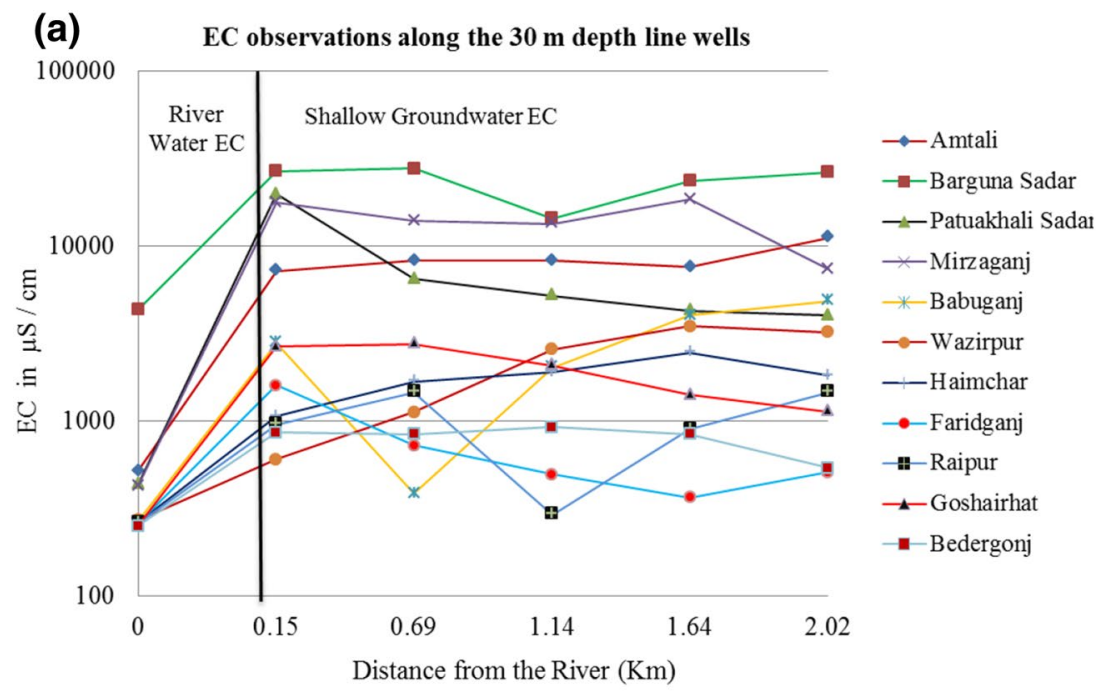

(b)

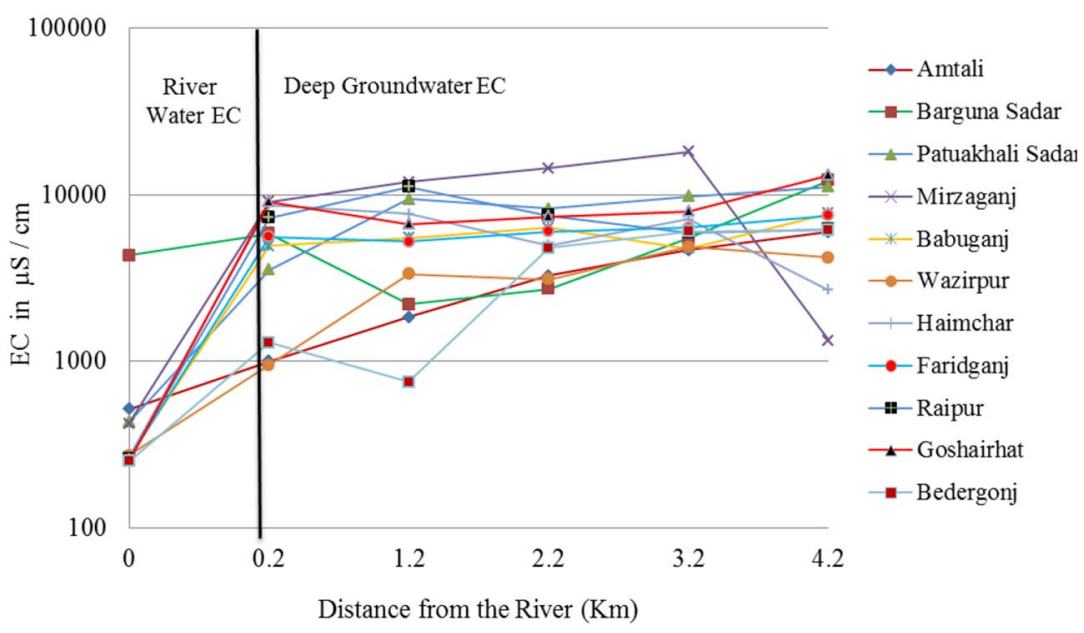


EC values show dissimilar trends from rivers to shallow aquifers in the study locations. In Fig. 7a all groundwater samples of nearest wells to river show higher EC values than river water samples and other groundwater samples show irregular pattern suggesting mixing up of freshwater and saline water.

In Fig. 7b, most groundwater samples of nearest wells to river show higher EC values than river water samples, while only one groundwater sample has less value. Other groundwater samples shows irregular pattern in $E C$ values suggesting mixing facies of cation-anion through the groundwaters, seawater and aquifers material. The lithology of the study area is mainly composed of sand and clay; and, sand is very resistant to weathering, while clay can affect the salt contents by absorption or desorption of ions from groundwater.

\subsection{Salinity distribution}

A sharp variation in salinity distribution has been observed in river water, shallow groundwater and deep groundwater, respectively (Fig. 8). Most of the river waters in the sample region contain salinity levels ranging from 0.10 to $4.45 \mathrm{ppt}$, except for the Kalapara upazila in the Patuakhali district, which shows this value $>4.45 \mathrm{ppt}$. It seems that the salinity distributions are almost dissimilar between shallow and deep groundwater. The salinity concentration range in shallow groundwater is 0.1 to $16 \mathrm{ppt}$, which is higher than the deep groundwater range of $0.4-10 \mathrm{ppt}$. The concentration rate of salinity is higher in the southern portion of the study region and decreases gradually from coast to inland in both rivers and shallow groundwater. In the extreme southern portion, the deep groundwater salinity concentration is very low, which may imply a lack of salinity data in the southernmost portion.

According to the Department of Water, Government of Western Australia [19], freshwater contains
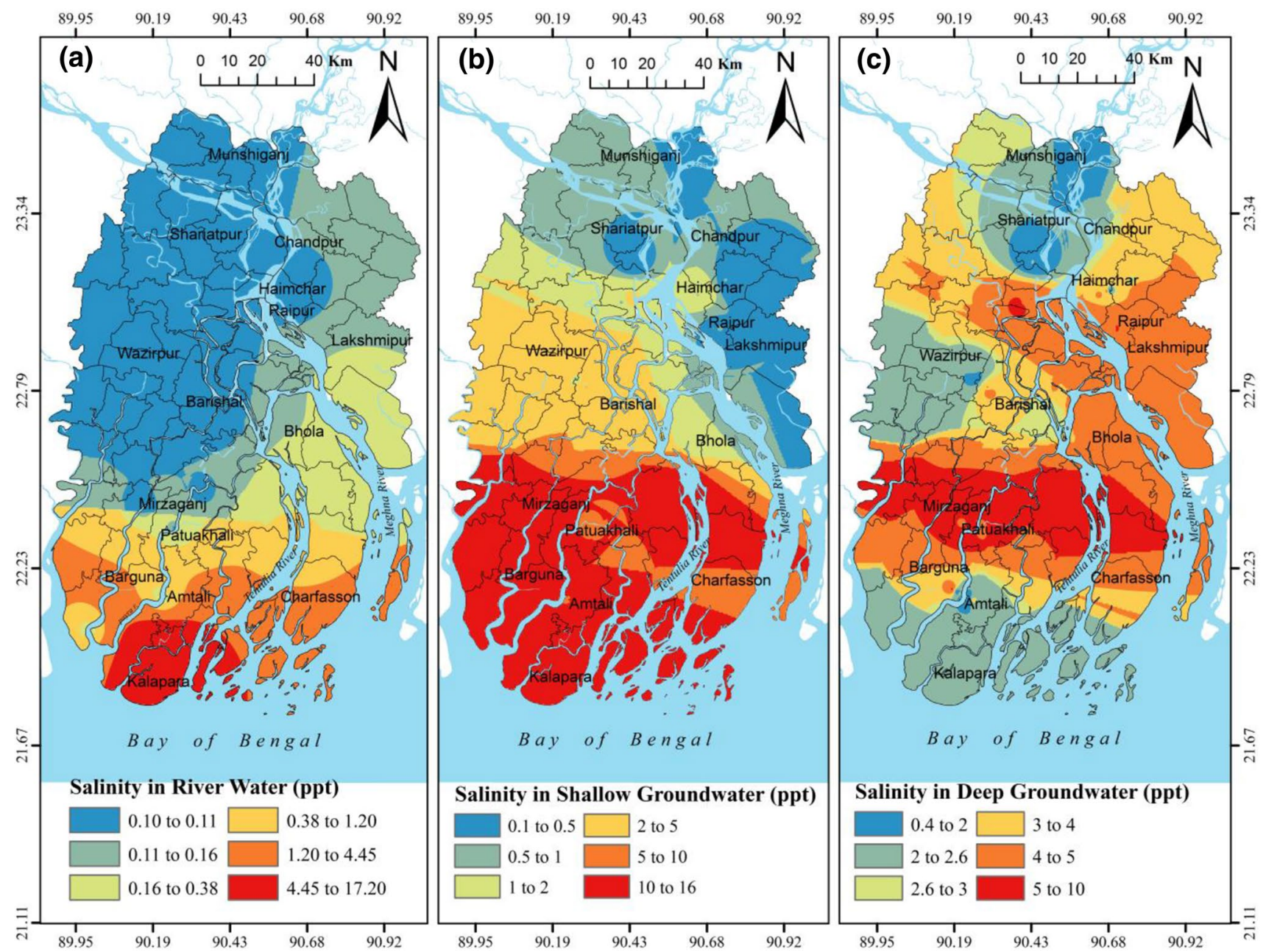

Fig. 8 Illustrating the salinity distribution maps of the river water, shallow groundwater and deep groundwater 
salinity values $<0.5 \mathrm{ppt}, 0.5-1 \mathrm{ppt}$ in marginal water, 1-2 ppt in brackish water, 2-10 ppt in ordinary saline water, 10-35 ppt in extremely saline water and seawater contains salinity values $>35 \mathrm{ppt}$. In this research, it appears that the brackish water in the shallow aquifer reaches the Barishal district, and passes the Shariatpur district in the deep aquifer (Fig. 8).

\section{Conclusions}

Interactions between river water and groundwater have been identified on the basis of multiple perspectives, and it has been found that river water and shallow groundwater are less affected by seawater than deep groundwater. Hydrochemistry, hydrochemical facies evaluation and salinity distributions justify these interactions among river water, groundwater and seawater. Groundwater flow and electrical conductivity (EC) also enhance an understanding of their interactions.

Piper and HFE-D diagram indicates the three sources are interconnected by hydrochemical facies dynamics. Both HFE-D diagrams for shallow groundwater and deep groundwater clearly suggest that a transgression of seawater of the Bay of Bengal has taken place into the coastal aquifer of Bangladesh. In the assessment of river water samples, approximately 82 percent of facies are characterized by freshening phases and 18 percent by intrusion phases suggesting the predominance of freshwater recharge and the insignificant mixing of seawater. Shallow groundwater samples exhibit that there are 14 facies characterized by 53 percent freshening phases and 47 percent intrusion phases indicating the mixing of freshwater and seawater in the shallow aquifer. Finally, deep groundwater reveals that there are only four hydrochemical facies identified and 78 percent corresponding to intrusion phases and 22 percent to freshening phases, strongly suggested intrusion of seawater by reverse cation exchange reactions. Observations of irregular trends of electrical conductivity $(E C)$ values, dissimilar salinity distribution of three sources water, multiple ion exchange process and direction of groundwater flow are also likely to follow the interactions of river water to shallow groundwater and shallow to deep groundwater. Excess concentration of $\mathrm{Na}^{+}$and $\mathrm{Cl}^{-}$ions alerts about saline pollution in groundwater specially in deep groundwater, and $\mathrm{HCO}_{3}{ }^{-}$along with $\mathrm{Na}^{+}, \mathrm{Ca}^{2+}, \mathrm{Mg}^{2+}$ in river water indicates mixing of freshwater and saline seawater, which could have harmful effects both in coastal delta aquatic life and in agriculture. Nitrate concentrations in both shallow and deep groundwater warn the drinking standard and also notify us that anthropogenic activities are leading up to this pollution.
The coastal aquatic system of Bangladesh is regularly experiencing frequent cyclones and storms, sea level rising, tidal activity and excess freshwater pumping which are key causes of salinization and other harmful contamination in fresh groundwater and river water.

Research was conducted on the basis of data from a single dry season, and the related geomorphological and structural data for rivers and aquifers could not be provided in this report. This study further exacerbates the need for a combination of field methods with other advance hydrogeological studies for identifying, explaining and evaluating river water-groundwater interactions in the Bangladesh Coastal Delta.

Acknowledgements Authors would like to express gratitude to Bangladesh Water Development Board (BWDB), Ministry of Water Resources (MoWR) and Bangladesh Climate Change Trust (BCCT), Ministry of Forest, Environment and Climate Change for implementing the project under which the data have been generated and used for this study. The authors are also thankfully acknowledged to the review and editorial team of SN Applied Sciences.

\section{Compliance with ethical standards}

Conflict of interest The authors declare that there is no conflict of interests to submit this article in this journal.

Open Access This article is licensed under a Creative Commons Attribution 4.0 International License, which permits use, sharing, adaptation, distribution and reproduction in any medium or format, as long as you give appropriate credit to the original author(s) and the source, provide a link to the Creative Commons licence, and indicate if changes were made. The images or other third party material in this article are included in the article's Creative Commons licence, unless indicated otherwise in a credit line to the material. If material is not included in the article's Creative Commons licence and your intended use is not permitted by statutory regulation or exceeds the permitted use, you will need to obtain permission directly from the copyright holder. To view a copy of this licence, visit http://creativecommons .org/licenses/by/4.0/.

\section{References}

1. Brammer H (2014) Bangladesh's dynamic coastal regions and sea-level rise. J Clim Risk Manag 1:51-62. https://doi. org/10.1016/j.crm.2013.10.001

2. Faneca Sanchez M, Bashar K, Janssen GMCM, Vogels M, Snel J, Zhou Y, Stuurman R, Dude Essink GHP (2015) SWIBANGLA: Managing salt water intrusion impacts in coastal groundwater systems of Bangladesh, $\mathrm{p} 153$

3. Dasgupta S, Hossain MM, Huq M, Wheeler D (2014) Climate change, groundwater salinization and road maintenance costs in coastal Bangladesh, Policy Research Working Paper 7147, World Bank Group

4. Dasgupta S, Kamal FA, Khan ZH, Choudhury S, Nishat A (2014) River salinity and climate change: evidence from coastal Bangladesh, Policy Research Working Paper 6817, World Bank Group

5. Islam ARMT, Siddiqua MT, Zahid A, Tasnim SS, Rahman MM (2020) Drinking appraisal of coastal groundwater in Bangladesh: 
an approach of multi-hazards towards water security and health safety. J Chemosphere. https://doi.org/10.1016/j.chemospher e.2020.126933

6. Naus FL, Schot P, Groen K, Ahmed KM, Griffioen J (2019) Groundwater salinity variation in Upazila Assasuni (southwestern Bangladesh), as steered by surface clay layer thickness, relative elevation and present-day land use. J Hydrol Earth Syst Sci 23:1431-1451. https://doi.org/10.5194/hess-23-1431-2019

7. Zahid A, Rahman A, Hassan MR, Ali MH (2016) Determining sources of groundwater salinity in the multi-layered aquifer system of the Bengal Delta, Bangladesh. BRAC Univ J 11(2):37-51

8. Rahman MM, Bhattacharya AK (2014) Saline water intrusion in coastal aquifers: a case study from Bangladesh. J Eng, Int Organ Sci Res 04(01):07-13

9. Rahman MA, Islam MN (2018) Scarcity of safe drinking water in the South-West Coastal Bangladesh. J Environ Sci Nat Res 11(1 \& 2):17-25

10. Shammi M, Rahman MM, Bondad SE, Bodrud-Doza M (2019) Impacts of salinity intrusion in community health: a review of experiences on drinking water sodium from coastal areas of Bangladesh. J Healthc 7:50

11. Todd DK (1995) Groundwater hydrology, 2nd edn. John Wiley, New York, pp 515-516

12. Bomer EJ, Wilson CA, Hale RP, Hossain ANM, Rahman FMA (2020) Surface elevation and sedimentation dynamics in the GangesBrahmaputra tidal delta plain, Bangladesh: evidence for mangrove adaptation to human induced tidal amplification. J Catena 187:104312

13. Giménez-Forcada E (2010) Dynamic of seawater interface using hydrochemical facies evolution diagram (HFE-D). Ground Water
48(2):212-216. https://doi.org/10.1111/j.1745-6584.2009.00649 .$x$

14. Piper AM (1944) A graphic procedure in the geochemical interpretation of water-analyses. EOS, Am Geophys Union 25(6):914-928

15. Giménez-Forcada E (2019) Use of the hydrochemical facies diagram (HFE-D) for the evaluation of salinization by seawater intrusion in the coastal Oropesa plain: comparative analysis with the coastal Vinaroz plain, Spain. Hydro Res 2:76-84

16. Kura NU, Ramli MF, Sulaiman WNA, Ibrahim S, Aris AZ, Mustapha $A$ (2013) Evaluation of factors influencing the groundwater chemstry in a small tropical island of Malaysia. J Environ Res Publ Health 10:1861-1881

17. Younger PL (2007) Groundwater in the environment: an introduction, 1st edn. Blackwel Publishing, Newcastle

18. Giménez-Forcada E (2014) Space/time development of seawater intrusion: a study case in Vinaroz coastal plain (Eastern Spain) using HFE-Diagram, and spatial distribution of hydrochemical facies. J Hydrol 517:617-627

19. Department of Water: Government of Western Australia (2020) Understanding salinity, http://wadow.clients.squiz.net/water topics/water-quality/managing-water-quality/understandingsalinity. Cited 02 March 2020

Publisher's Note Springer Nature remains neutral with regard to jurisdictional claims in published maps and institutional affiliations. 